\title{
Probability, odds and random chance: the difficult task of modulating the epigenetic profile of cloned embryos
}

\author{
Luís Henrique de Aguiar $^{1,2}$, Elvis Ticiani ${ }^{1,2}$, Paula Rodriguez-Villamil ${ }^{1}$, Felipe Ledur Ongaratto $^{1}$, Cícera \\ Regina Lazzarotto $^{2}$, José Luiz Rodrigues ${ }^{1}$, Luciana Relly Bertolini ${ }^{2}$, Marcelo Bertolini ${ }^{1,3}$ \\ ${ }^{1}$ Embryology and Reproductive Biotechnology Lab, Federal University of Rio Grande do Sul (UFRGS), \\ Porto Alegre, RS, Brazil. \\ ${ }^{2}$ Genetic Engineering and Biotechnology Lab, Pontifical Catholic University of Rio Grande do Sul (PUCRS), \\ Porto Alegre, RS, Brazil.
}

\begin{abstract}
Since the beginning of modern embryology, scientists have wondered about how a small number of totipotent embryonic cells can become an individual with a wide variety of organs and tissues with distinct functions. Also, the idea of generating a cloned animal using a nucleus from a donor cell is not recent. However, it has taken years of research to achieve this goal, especially regarding mechanisms of cell reprogramming required to return a differentiated cell to totipotency. Cloning by somatic cell nuclear transfer (SCNT) has been a valuable tool to understand epigenetic mechanisms related to cellular reprogramming. However, cloning efficiency is still low, with a low percentage of embryos resulting in healthy animals. The high attrition rate is associated with incomplete or abnormal epigenetic reprogramming, such that many cloned embryos have DNA methylation patterns different than controls, resulting in faulty gene expression and subsequent developmental failures. Attempts to improve genome reprogramming by modulation of oocyte quality and/or somatic cell plasticity, thereby increasing cloning efficiency and preventing detrimental effects on development, have proven ineffective. The recent development of DNA editing techniques may facilitate an improved understanding of cellular reprogramming and the role of DNA methylation in development. These novel tools may lead to new means to modulate epigenetic programming and inheritance, and hold great promise to assist in epigenetic remodeling of the donor nucleus. Such strategies are likely to improve the odds for successful cloning.
\end{abstract}

Keywords: cloning by nuclear transfer, embryo development, epigenetics, reprogramming.

\section{Introduction}

Among many questions of biological significance, one in special has intrigued embryologists for a long time: how can cells change their phenotypes without changing the genotype? The concept of genomic equivalence, in which each somatic cell in the organism has the same genetic material and, therefore, also has all the information necessary to create a complete new organism, was assumed as a fact for decades, since cells are all derived from one single cell fertilized egg. However, the ultimate evidence came only in 1996 with the birth of Dolly, the sheep, cloned by somatic cell nuclear transfer (SCNT) procedures using somatic cells from an adult ewe (Wilmut et al., 1997). At last, animal cloning demonstrated that a differentiated somatic cell nucleus could be re-directed (or reprogrammed) for the development of an entire new organism. Since then, more than 20 vertebrate species have been cloned, from a variety of somatic cells, for a multitude of purposes, at various levels of success, demonstrating the usefulness of the procedure for applications ranging from science to the industry, animal conservation to production, genetic selection to transgenesis.

Twenty years after Dolly has passed, and cloning efficiency still remains low. Despite efforts to improve it, less than $5 \%$ of the animals come to term and remain healthy afterwards (Selokar et al., 2014, 2015). Even though the precise factors are yet to be determined, such low efficiency is undoubtedly associated with incomplete or abnormal chromatin remodeling and genomic reprogramming after cloning, which is related to nonphysiological epigenetic modifications dependent on (i) the quality of the recipient oocyte or cytoplast where the donor nucleus need to be reprogrammed (Wells et al., 2010; Aguiar et al., 2016), (ii) the origin, quality, and plasticity of the donor nucleus or karyoplast per se prior and after its transfer into a cytoplast (Campbell et al., 2005), and (iii) the level of technical expertise and biological variation in all steps related to cloning (Bertolini et al., 2012). For normal embryo development and survival, success in cloning depends on correctly reversing specific markers of cellular differentiation to reactivate or resume processes needed during development, all associated with proper specific and global gene expression (Niemann, 2016).

Even with the concept of genomic equivalence, the ideia that the genome can be strongly affected by external or environmental influences lay the ground basis for what is referred as epigenetics, and what such a field is about: how genes are regulated, what factors can influence them, and how genes control and are controlled in the course of development throughout life, under physiological or pathological conditions, and in health and disease. In that regard, animal cloning still is a useful model to dedifferentiate specialized somatic cell nuclei to a totipotent state, in a process referred as epigenetic reprogramming. Thus, this review aims to briefly discuss some concepts and views on the role of epigenetic and reprogramming mechanisms in growth 
and development, especially after cloning by SCNT, including attempts to epigenetically modulate gene function and normal development.

\section{Chromatin remodeling, epigenetic reprogramming, and early events in development}

Nuclear remodeling after cloning or remodeling of chromosomal architecture is the designation for a series of molecular events involving modification and expression of nuclear laminins (Kubiak et al., 1993), formation of the nuclear envelope (Szollosi and Szollosi, 1988), and changes in protein synthesis (Fulka et al., 1996). The cytoplasmatic kinase named Mitosis or Meiosis Promoter Factor (MPF) has great importance in the nuclear remodeling (Campbell, 2002, 2013). The kinase activation triggers the onset of mitosis or meiosis, resulting in nuclear envelope break (NEBD), chromatin condensation, reorganization of the cytoskeleton and changes in cell morphology (Nurse, 1990; Campbell, 2002, 2013).

It has not been determined if the nuclear remodeling is an absolute necessity for the normal development of cloned embryos. However, it has been demonstrated for quite some time now that nuclear MPF facilitates remodeling after cloning (Fulka et al., 1996). In metaphase II (MII) oocytes containing high levels of MPF active kinase, the maintenance of the cytostatic factor (CSF) that keeps MPF active remains until oocyte fertilization or activation (Fulka et al., 1996; Marteill et al., 2009). After the steps of fusion/activation in conventional cloning procedures, the kinase activity of MPF phosphorylates numerous cellular proteins leading to the completion of meiosis II, the remodeling of the maternal and paternal chromatin, also contributing to the embryonic activation process (Sirard, 2011).

In cloning, among the most notorious events of the MPF action in the MII oocyte on the donor nucleus, usually at the G0/G1 stages of the cell cycle, are the breakdown of the nuclear envelope, the premature chromatin condensation (PCC) and the formation of the achromatic spindle, which culminates in the extrusion of the second polar body (Campbell, 2013). Conversely, after fertilization, embryonic activation follows, when CSF is degraded and the MPF activity decreases in the first hours, coinciding with the nuclear envelope reconstruction in the form of male and female pronuclei and chromatin decondensation, initiating an interphase (Szollosi et al., 1988; Nakai, 2016). In cloned embryos, which are artificially activated by electrical or chemical processes, MPF activity remains high for a longer period of time (Kubiak et al., 1993; Sterthaus, 2009). Currently, researchers are still trying to identify factors and their importance in the success or failure of epigenetic reprogramming after cloning, seeking the understanding of how to improve protocols and processes to attain more reliable results.

Intrinsic and extrinsic modulators of epigenetic reprogramming and early development after cloning

Animal cloning by SCNT, although simple in concept, involves multiple steps that make the process complex, a fact responsible for its success or failure in subsequent development (Bertolini et al., 2012). Some steps, e.g., oocyte in vitro maturation (IVM) or in vitro culture (IVC) of embryos, are common to other in vitro embryo production (IVP) systems, such as in vitro fertilization (IVF) procedures. However, other steps are exclusive to cloning, such as those that replace fertilization by SCNT.

The cloning success is directly associated with the source, quality and preparation of enucleated recipient cytoplasms (cytoplasts), the donor cell nucleus (karyoplasts), and also cloning procedures per se, including embryo reconstruction and activation (Campbell et al., 2005; Wells, 2010). Therefore, the intrinsic features of cytoplasts and karyoplasts are modulated by physical and chemical factors, including manipulation and ex corpore exposure, which is always a suboptimal environment and biologically less suitable for development (Bertolini et al., 2012).

\section{Cytoplast source and cell cycle synchrony/asynchrony}

The oocyte source is a limiting factor for many species, in terms of availability, quality and biological competence, also being one of the main sources of variation in programs of in vitro embryo production (Galli et al., 2003; Wells, 2010). In vivo-matured oocytes are routinely used for cloning in many animal species, as such oocytes are presumably more competent for nuclear reprogramming and to subsequent embryonic development (Campbell et al., 2005; Ribeiro et al, 2009; Wells, 2010; Mezzalira et al., 2011; Aguiar et al., 2016).

The cytoplast appears to be one of the key elements for cloning success as everything associated with the oocyte is essential for embryonic and subsequent fetal development, still being one of the most efficient milieu for the induction of epigenetic reprogramming of the genome (Campbell et al., 2005). Reprogramming factors, for example, must be abundant and sufficient present to effectively reprogram a genome (Campbell et al., 2001; Oback and Wells, 2003; Wen et al., 2014). It is believed that nuclear reprogramming capacity reaches its highpoint from fertilization/reconstruction up to the embryonic genome activation, as the oocyte cytoplasm contains chromatin remodeling factors and reprogramming factors (proteins, mRNAs, miRNAs and molecular precursors) accumulated during folliculogenesis (Alberio et al., 2001; Urrego et al., 2015). However, factors acting in the reprogramming of the donor nucleus are still not completely identified, with the oocyte quality remaining key to successful animal cloning (Wells, 2010).

Pieces of evidence suggest that the start in embryonic genome expression occurs early in development (Flach et al., 1982; Graf et al., 2014), leading to the hypothesis that the nucleus requires a time to adapt to a new cellular environment. Once the oocyte environment is at a state of transcription, a transferred nucleus donor would not have adequate time to adapt, negatively affecting nuclear reprogramming. This leads to another important point of discussion, 
which is related to the level of synchrony between the cell cycles of the recipient cytoplasm and the donor cell.

It is known that the exposure of a donor nucleus to an environment with active MPF, such as in the MII oocyte, will lead to a series of subcellular events promoting exposure of chromatin reprogramming factors also at high levels in the cytoplasm, which possibly favors epigenetic reprogramming (Mezzalira et al., 2011). Thus, in vitro embryo development is improved when cytoplasts at MII are used in association with post-fusion activation (Heyman et al., 2002; Mezzalira et al., 2011). The time between the fusion of the cytoplast at MII with the karyoplast at G0/G1 and embryo activation is referred as reprogramming time, and such time appears to play an important role in chromatin exposure to oocyte cytoplasmic remodeling factors (Campbell et al., 2005). The appropriate reprogramming time usually ranges from 1 to 4 hours, but no consensus exists about the ideal exposure time under each separate condition.

\section{MII oocytes as cytoplasts}

Generally, classic cloning procedures, from Briggs and King (1952) to this day, use enucleated oocytes at MII as recipient cytoplasts. For such cloning protocols, the karyoplast cell cycle can be used either at the $\mathrm{G} 1$ phase, which is the interval between mitosis (M phase) and onset of DNA replication (S phase), or at the G0 phase (Wilmut et al., 1997; Kato et al., 1998; Heyman et al., 2002), with cell remaining metabolically active but mitotically quiescent (Oback and Wells, 2002). Then, the somatic cell nucleus must always adopt the parameters of the cell cycle of the MII recipient cytoplast (Kikyo and Wolffe, 2000). As non-activated MII cytoplasts have high MPF levels, donor nuclei are forced into the $\mathrm{M}$ phase, with cells at $\mathrm{G} 0 / \mathrm{G} 1$ remaining diploid, whereas cells at the $\mathrm{G} 2$ or at the $\mathrm{S}$ phases result in aberrant chromosome configurations (Oback and Wells, 2002). In such cases, if the cloning protocol does not allow the extrusion of the second polar body, the resulting embryo may become tetraploid or, at its best, the rupture of the nuclear envelope and premature chromatin condensation (if DNA synthesis is not complete) can lead to aneuploidy and chromosome loss (Barnes et al., 1993, Østrup, 2009). Then, cell cycle synchronization into G0/G1 is usually attained by many procedures to ascertain proper embryo development after cloning (Gerger et al., 2010).

\section{Universal cytoplast}

Pre-activated oocytes are referred as universal cytoplasts when used for cloning after the decrease in MPF activity, as such cytoplast is compatible with development using cells at any stage of the cell cycle. Under all situations, resolution of ploidy will occur, as there is neither the breakdown of the cell nuclear envelope at the interphase nor a premature chromatin condensation (Campbell et al., 1996). Nevertheless, the use of such oocytes usually results in lower rates of development. Similarly, aged oocytes have lowering
CSF levels due to gradual decay, destabilizing MPF, leading to an increase in spontaneous activation by physicochemical environmental events (Wakayama et al., 2003). However, despite being easier to activate, aged oocytes have lower potential for further embryo development (Chian et al., 1992; Takahashi, 2013).

\section{Late TII oocytes as cytoplasts}

As an additional oocyte source for cloning, also related to the cell cycle, the embryo reconstruction using oocytes at late telophase II (Bordignon and Smith, 1998) results in proper embryo development, but at slightly lower rates than MII oocytes, possibly due to MPF levels still being abundant to trigger events observed with MII oocytes, some associated with reprogramming and chromatin remodeling (Mezzalira et al., 2011). Such system is successfully in use in commercial cloning operations in Brazil and abroad.

\section{Karyoplast or nuclear donor cell type}

The choice of the karyoplast or nuclear donor cell type has a significant biological impact on cloning and accounts for large variations in the success rates (Campbell et al., 2005, Liu et al., 2015). Cellular reprogramming efficiency after SCNT seems to depend on a multitude of factors, including the genotype (species, breed, gender, age, individual factor, etc.), the stage of development (embryonic, fetal, adult animal), tissue origin, cell type, degree of differentiation, cell cycle, and overall features when in culture (Batchelder et al., 2005; Wells, 2010). As mentioned above, the current understanding is that most of the cloning efficiency is associated with the use of synchronized somatic cells at G0 or G1 of the cell cycle (Wilmut et al., 1997; Wakayama et al, 1998; Wells, 2010). In addition, cells of embryonic origin seem to present a higher potential for further development and lower level of abnormalities than cells from fetal origin, which in turn seem to be more efficient than adult cells (Heyman et al., 2002; Batchelder et al., 2005). Cells from the same individual but from different tissue origins at distinct differentiation levels have also been described to favor cells of lower degree of differentiation (Batchelder et al., 2005). Likewise, the isolation method, the type of cell culture and the number of cell passages have an important effect on the results (Wells, 2010; Martins et al., 2016), whereas cells with few passages in culture appear to exhibit greater potential for epigenetic reprogramming after cloning (Li et al., 2014). All these aspects should be carefully controlled, as it is known that the culture conditions can cause genomic instability and consequent failures after cloning (Humpherys et al., 2001). Nonetheless, the small number of reported births, the absence of extensive controlled studies, and the low technical efficiency make it a difficult task to adequately compare cell types in cloning by SCNT (Tecirlioglu et al., 2005).

\section{Embryo reconstruction procedures}

The embryo reconstruction itself can be accomplished by micromanipulation with (Wilmut et 
al., 1997) or without (Oback and Wells, 2003) zona pellucida, or manually by handmade cloning (HMC) without zona pellucida (Vajta et al., 2003), with no apparent differences in the final efficiency between procedures (Tecirlioglu et al., 2005). Usually, embryo reconstruction by SCNT involves the steps of oocyte enucleation, nucleus transfer by membrane fusion with the mix of different cytoplasms, oocyte activation and embryo culture. Oocyte enucleation may result in loss of cytoplasm and, when excessive, can compromise subsequent embryo development (Ribeiro et al., 2009). On the other hand, the fusion of cell membranes leads to mosaicism and cytoplasmic heteroplasmy by mixing different cytoplasts, and it is still not clear which are the possible biological consequences on subsequent development (Ribeiro et al., 2009; Mezzalira et al., 2011). In addition, fusion aims to introduce a donor nucleus, typically at the G0/G1 phases of the cell cycle, into a MII oocyte. Such process exposes the chromatin to reprogramming factors and to heterologous proteins and miRNAs, all likely important for genome reprogramming (Alberio et al., 2001).

Oocyte or embryo activation also appears to be related to the possible development problems since, physiologically, it occurs by the action of factors released by the sperm cell, causing intracellular periodic oscillations in intracellular $\mathrm{Ca}^{2+}\left(\left[\mathrm{Ca}^{2+}\right]_{\mathrm{i}}\right)$ in the oocyte for a certain period of time, which depolarizes the cell membrane and induces a chain of events that leads to embryo activation and the first embryo cleavage (Galli et al., 2003). In cloning by SCNT, activation of the reconstructed embryo is usually induced artificially by electric or chemical procedures, leading to elevated $\left[\mathrm{Ca}^{2+}\right]_{\mathrm{i}}$ in a single peak. Moreover, the use of inhibitors of protein kinases (targeting MPF) or protein synthesis (blocking cyclin translation), especially for cells at $\mathrm{G} 0 / \mathrm{G} 1$, is deemed necessary for further embryo development (Campbell et al., 2005). Finally, the in vitro embryo culture system has also been implicated with epigenetic changes, resulting in distinct gene expression patterns in embryos and in embryonic stem cells (Dean et al, 1998; Wrenzycki et al., 2001).

Altogether, the summation of intrinsic and extrinsic factors related to the cytoplast source and karyoplast type, along with the biological and technical aspects in all steps involved in cloning procedures per se, ultimately will determine the overall cloning efficiency, which is by far and large dependent on the level of genome reprogramming at early embryo stages, making animal cloning a process of survival of the epigenetically fittest (Bertolini et al., 2012).

\section{Improving genome reprogramming: is it feasible?}

Overall, and despite such variety in the idiosyncrasies and peculiarities to reach success after cloning by SCNT, once a minimal understanding of the methodology, certain levels of skill and experise, and the control of some basic biological factors are attained, obtaining cloned blastocysts is a relatively easy outcome. Still, blastocyst yield does not necessarily reflect success. An example is the possibility of achieving high blastocyst rates by parthenogenesis, a procedure commonly used to infer oocyte quality (Ribeiro et al., 2009). Thus, although blastocyst yield is a rather easy pitfall to overcome, proof of success after cloning can only be certified when there is subsequent in vivo development after the embryo transfer (ET) to recipient females, culminating with the birth of viable offspring (Bertolini et al., 2012).

Pre- and postnatal abnormalities observed after cloning by SCNT are directly related to the efficiency of each step in embryo reconstruction. In the process, the functional and molecular asynchrony between donor nucleus and ooplasm components leads to inadequate genomic reprogramming. This fact is well demonstrated by several groups in which mammalian cloned embryos have an abnormal genome epigenetic configuration associated with phenotypic and physiological changes during development (Dean et al., 2001; Wrenzycki et al., 2001; Beaujean et al, 2004). Such features support the hypothesis that failures at the level of gene expression and embryonic development are caused by improper reprogramming of the donor genome during and after SCNT, due to many of the factors and components already discussed above, affecting the pattern of DNA methylation, or histone acetylation, methylation, phosphorylation or ubiquitinization during the first rounds of embryo development, compromising proper gene function and development afterwards.

\section{Role of DNA methylation in development}

DNA methylation in mammals is an important regulator of gene transcription, being a mechanism often used to silence and regulate genes without changing the original DNA sequence; this is one of the most important strategies for epigenetic modifications of the genome (Jaenisch and Bird, 2003). Biochemically, DNA methylation is a process involving the addition of a methyl group at position 5 of cytosine residues $(5 \mathrm{mC})$ in the DNA. In adult somatic cells, the DNA methylation typically occurs in dinucleotide sequences called $\mathrm{CpG}$ islands, which are in guanine- and cytosinerich regions. Between 60 and $90 \%$ of all CpGs are methylated in mammals (Tucker, 2001), and these islands are usually also present in the 5 ' regulatory regions of many genes, which are also associated with differentially methylated regions (DMR), directly related to genomic imprinting.

DNA methylation is essential for normal development and performs a variety of biological functions, being associated with very important processes, including repression of gene expression, genomic imprinting, X-chromosome inactivation, suppression of repetitive elements and carcinogenesis. Thus, the relationship between DNA methylation and chromatin structure is very important because this epigenetic modification affects cell function, allowing cells with the same genetic material to differentiate, yielding multiple organs, or perform various functions (Jaenisch and Bird, 2003). DNA methylation can also suppress the expression of endogenous retroviral genes and other deleterious DNA sequences that may have 
been incorporated into the host genome over time. The methylation can also protect DNA from enzymatic cleavage because most restriction enzymes are incapable of recognizing and binding to sequences (epigenetically) modified externally.

As one of the most important functions, DNA methylations at CpGs have the specific effect of reducing gene expression, being found in all vertebrates, with extensive evidence that genes with high levels 5methylcytosine in their promoter region are transcriptionally silenced (Jaenisch and Bird, 2003), as shown in Fig. 1. DNA methylation can affect gene transcription in at least two ways: 1) physically preventing the binding of transcription proteins; and/or 2) binding proteins known as MBDs (methyl-CpG-binding domain proteins). These proteins may recruit additional proteins to the site, such as histone deacetylases and other chromatin remodeling proteins that can modify histones, thereby forming a compact and inactive chromatin called heterochromatin (Nan et al., 1993).

(a)

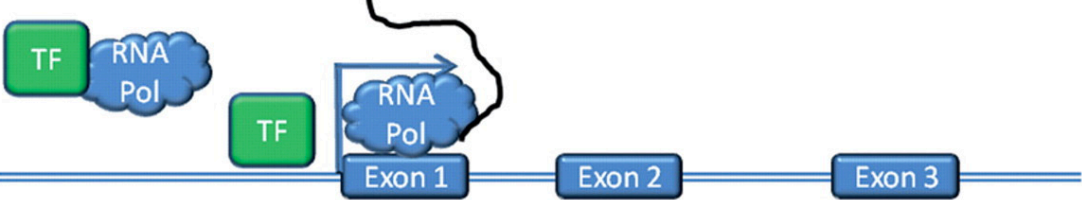

No CPG methylation in promoter nor in upstream island shores $\rightarrow$ active transcription

(b)

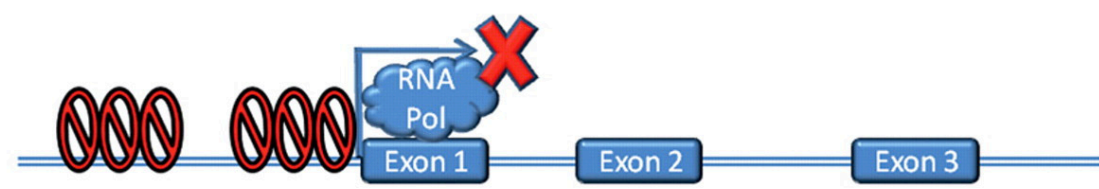

Methylated CPG islands $\rightarrow$ transcriptional repression

Figure 1. Regulation of gene transcription by DNA methylation. (a) Active transcription: unmethylated CpG islands at promoters of genes leads to active transcription. (b) Inactive transcription: hypermethylated $\mathrm{CpG}$ islands at promoters of genes leads to transcriptional repression. TF: transcription factors. RNA Pol: RNA polymerase. From Turunen and Ylä-Herttuala (2011).

Interestingly, no significant methylation pattern is seen in embryonic stem cells (Lister et al., 2009), but in somatic cells there are high levels of DNA methylation generally transmitted to daughter cells with high fidelity. Therefore, the resulting epigenetic changes are normally stable, continuous and unidirectional, preventing an organism from reverting any level of cell differentiation or the conversion of a tissue to another.

\section{Role of DNA Methyltransferases in development}

The pattern of global and specific DNA methylation in mammalian cells appears to be propagated during the development of the conceptus after each DNA replication cycle by an action of either de novo or maintenance DNA methyltransferases (Jackson-Grusby et al., 2001; Golding and Westhusin, 2003). DNA methyltransferases (DNMTs) are part of a family of enzymes that catalyze the transfer of a methyl group to the DNA using S-adenosyl-methionine (SAM) as a methyl donor (Smith et al., 1992). Like restriction enzymes, methyltransferases have specific target DNA sequences. In mammalian cells, DNMTs methylate DNA sequences in $\mathrm{CpG}$ islands, located generally closer to or within the promoter regions, and exhibit different patterns of DNA methylation, also determining the imprinting pattern. In such cells, DNA methylation that occurs mainly at the $\mathrm{C} 5$ position in $\mathrm{CpG}$ dinucleotides is done by two general classes of DNA methyltransferases: maintenance and de novo DNMTs (Smith et al., 1992). Three active DNMTs have been identified in mammals, being called (maintenance) DNMT1, and (de novo) DNMT3a, DNMT3b and DNMT3L (Golding and Westhusin, 2003).

\section{DNMT1}

The DNMT1 is the most abundant DNA methyltransferase in mammalian cells and is considered the main maintenance enzyme, predominantly methylating $\mathrm{CpG}$ di-nucleotides in the hemimetilated genome (Kho et al., 1998). The maintenance of methylation activity is necessary to preserve DNA methylation responsible for the copy of the methylation patterns for "daughter" strands after each cellular DNA replication cycle. In vitro, the enzyme is 7 to 100 times more active in hemimetilated DNA compared to non-methylated substrate and is more active in the de novo methylation than other DNMTs. DNMT1 has several isoforms: the somatic form, the most common in the organisms and always present in the nucleus of somatic cells; variant DNMT1b isoform; and DNMT1o, an oocyte-specific isoform, which is synthesized and stored in the cytoplasm of oocytes, being allocated in the nucleus during specific stages of early embryo development (Golding and Westhusin, 2003). Abundant levels of transcripts to the main isoforms of DNA methyltransferases are found in oocytes and embryos at preimplantation stages (from 1-cell to blastocyst) in cattle (Golding and Westhusin, 2003) and humans (Huntriss et al., 2004). The DNMT1o variant, present in 
murine and human oocytes and embryos, is unidentified in cattle (Golding and Westhusin, 2003).

\section{DNMT3}

The DNMT3 is a DNA methyltransferase family that may also methylate the $\mathrm{CpG}$ sites of unmethylated and hemimetilated DNA. The structure is similar to DNMT1, with a regulatory region linked to a catalytic domain, with three known members of the family: DNMT3a, DNMT3b, and DNMT3L. The DNMT3a and DNMT3b can mediate methylationdependent gene repression, with these enzymes able to establish DNA methylation patterns in early embryonic development and to promote cell differentiation. The DNMT3L is a protein homologous to the other DNMT3s, but with no catalytic activity. Such protein interacts with DNMT3a and DNMT3b, being co-located in the nucleus, aiding the DNA binding to the de novo methyltransferases, stimulating their activity (Rhee et al., 2002).

\section{Differentially methylated regions (DMRs) and genomic imprinting}

The DMRs are genomic regions with different states of methylation, with functional regions involved in regulating gene transcription, and a strong association with genomic imprinting, including imprinting control regions (ICRs) into DMRs. The identification of DMRs from various tissues may show epigenetic differences among them, as well as cancer DMRs can show aberrant methylation patterns when compared with normal samples (Irizarry et al., 2009). It is well known that DNA methylation is associated with cell differentiation and proliferation (Reik et al., 2001), also strictly related to distinct DMRs in development and through the reprogramming process (Meissner et al., 2008; Doi et $a l ., 2009)$. In addition, there are intra- and interindividual DMRs with longitudinal changes in the global methylation, increasing with age in a given individual or between individuals (Bjornsson et al., 2008; Bock et al., 2008).

The expression of imprinted genes crucial to development is also regulated at the epigenetic level by imprinting/methylation within DMRs, which regulate gene expression either from paternal or maternal alleles. One of the classical examples in imprinted gene regulation by imprinting/methylation within DMRs is played by the Igf2-H19 locus that encodes the pleitropic growth factor IGF2 and the H19 gene, which results in a non-coding RNA precursor of several microRNAs that have tumor suppressor effects (Reik and Murrel, 2000; Ratajczak, 2012; Singh et al., 2012), as illustrated in Fig. 2. Under normal imprinting pattern, a DMR positioned between the Igf 2 and $\mathrm{H} 19$ coding regions is unmethylated on the maternal allele, and methylated on the paternal counterpart, with the expression of both genes being under the regulation of a downstream 3'distal enhancer (Fig. 2a). The methylation of the paternal DMR prevents binding of the CTCF insulator protein, allowing the activation of the paternal Igf2 promoter by the distal enhancer. Conversely, as the maternal DMR is unmethylated, CTCF insulator protein binds to it, preventing the activation of the maternal Igf2 promoter, with the maternal $\mathrm{H} 19$ being transcribed. Then, the proper somatic imprint of the DMR at the Igf2-H19 locus, with a lack of methylation on the maternal allele and a methylation pattern of the paternal allele, ensures that Igf 2 is transcribed only from the paternal chromosome, and H19 only from the maternal chromosome, under a balanced expression pattern (Reik and Murrel, 2000; Ratajczak, 2012; Singh et al., 2012).

However, under certain epigenetic conditions, such as after faulty nuclear reprogramming following cloning by SCNT or in primordial germ cells (PGCs), the pattern of expression may change significantly, affecting pre-natal growth, development and survival to term. In the erasure of imprinting, when both DMRs at the Igf2-H19 locus are unmethylated, only H19 is transcribed from both parental alleles (Ratajczak, 2012). Conversely, in the loss of imprinting, when both DMRs at the Igf2-H19 locus are methylated, as seen in cancer cells in several cancer types, only Igf2 is expressed from both parental chromossomes (Fig. $2 b$ and c). The imprinting process appears to be more susceptible to environmental effects and faulty reprogramming, with deregulations of ICRs/DMRs and loss of imprinting, generally resulting in abnormal phenotypes (Rancourt et al., 2013). Consequently, embryonic manipulations, such as IVF and cloning by SCNT, should deregulate genomic imprinting (Moore, 2001).

\section{Physiological epigenetic changes in the course of development}

DNA methylation appears to be critical to the course of normal embryonic development in mammals, as chromatin remodeling after fertilization is closely related to a fast demethylation of the parental genome (Reik et al., 2001; Dean et al., 2003). As illustrated in Fig. 3, DNA methylation pattern in gametes is typically removed during early embryo stages, to be restored during the successive cell divisions in development, altering the stable gene expression during cell division and inducing cell differentiation. In fact, global genomic reprogramming occurs rapidly after fertilization, with the degree of DNA methylation decreasing in about $30 \%$ of the average level observed in somatic cells (Bird, 2002). This fact is interesting because when demethylation was experimentally induced below such values, a negative interference in embryonic development was observed, showing that a certain degree of methylation needs to be maintained in the genome (Giraldo et al., 2009). Following the reduction in DNA methylation during the first cleavages, a de novo methylation pattern is promoted by DNMT3a, $3 \mathrm{~b}$ and $3 \mathrm{~L}$ (Fig. 3), beginning at the 8-cell and at the blastocyst stages in cattle and mice, respectively (Dean et al., 2003). 


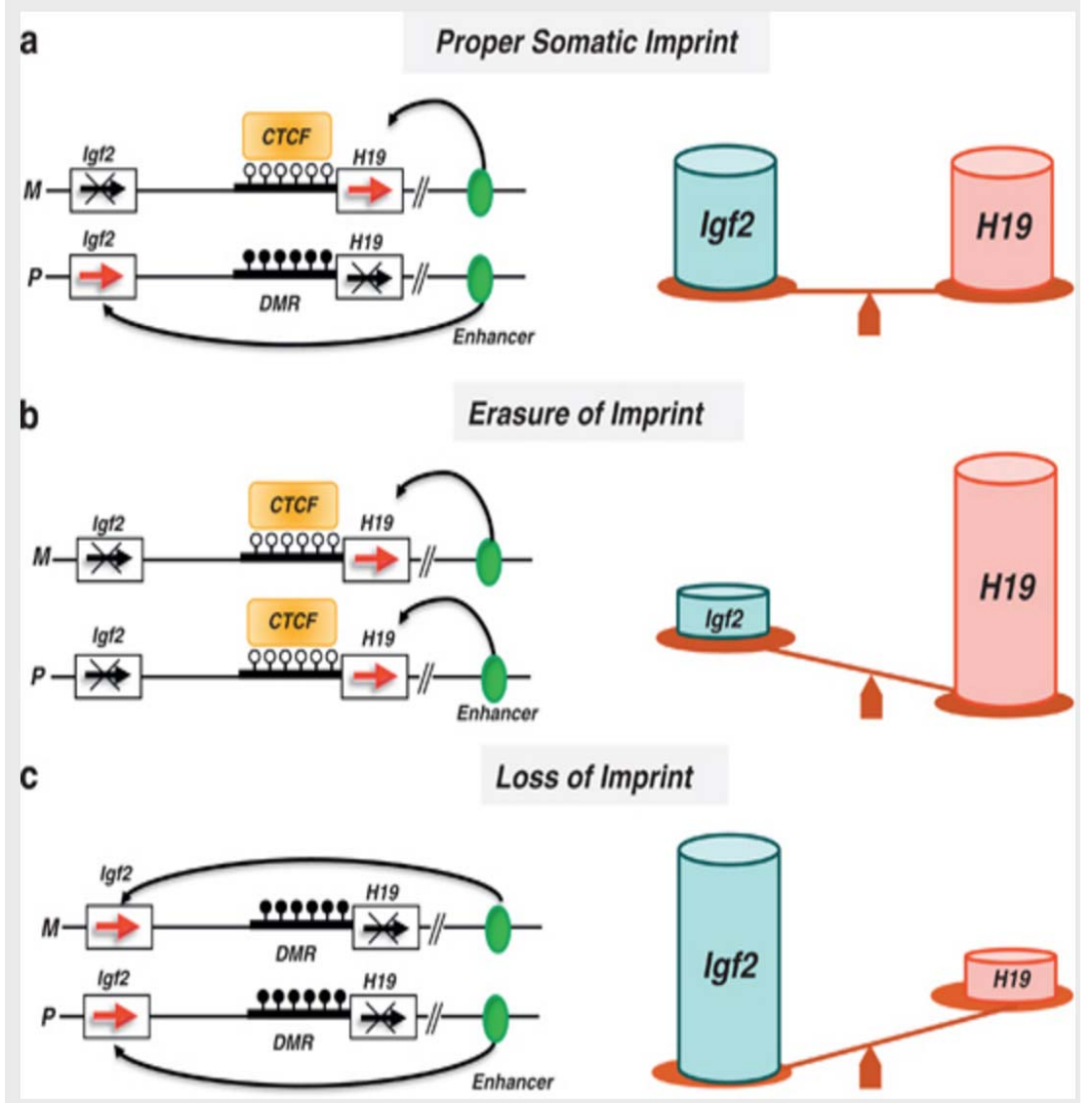

Figure 2. Regulation of expression pattern in the imprinted genes Igf-2 and H19 by changes in the methylation state in the DMR within the Igf-2-H19 locus, and expression balance (proportion) between genes. (a) Proper somatic imprint. (b) Erasure of imprint. (c) Loss of imprint. See text for details. M: maternal chromosome. P: paternal chromosome. CTCF: CTCF insulator protein. DMR: differentially methylated region. From Ratajczak (2012).

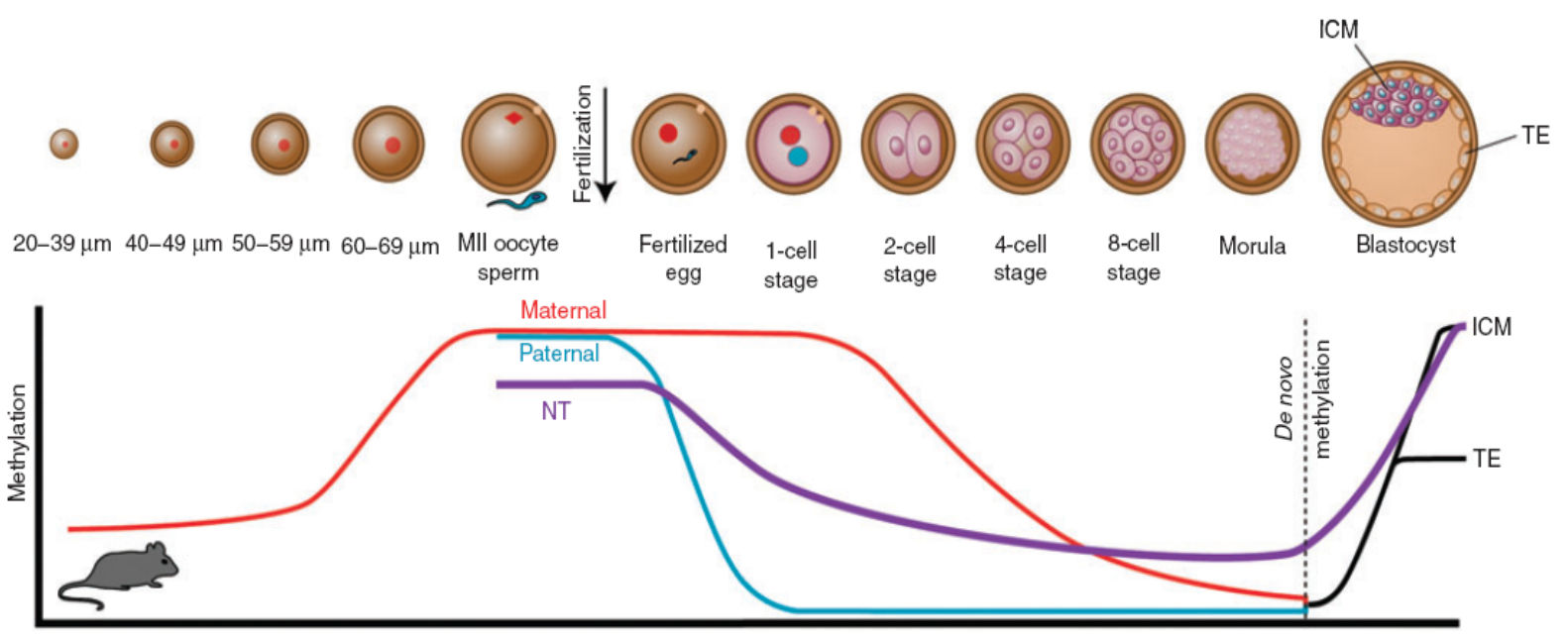

Figure 3. Methylation dynamics during normal early embryonic development and in clones. In the mouse, methylation of the germinal vesicle nucleus increases with size of the oocyte. After fertilization, a quick hydroxymethylation of the paternal genome (blue), previously thought to occur as an active demethylation process, and a passive demethylation of the maternal genome (red) occurs. De novo methylation occurs at the blastocyst stage, with a differential methylation pattern between the inner cell mass (ICM) and the trophectoderm (TE). In cloned embryos (purple), some demethylation takes place by the blastocyst stage, after nuclear transfer but before de novo methylation, with aberrant methylation (hypermethylation) of the TE. From Yang et al. (2007).

\section{Hydroxymethylation}

Until recently, the demethylation of the paternal genome was considered as part of an active process (replication independent), whereas in the maternal genome, the demethylation occurs passively 
during DNA replication (replication dependent) in each cell division (Yang et al., 2007). Pieces of evidence suggest that in fact a passive process also occurs in the paternal genome, by the convertion of 5'methylcytosine $(5 \mathrm{mC})$ into 5'-hydroximethylcytosine $(5 \mathrm{hmC})$ prior to demethylation per se (Wossidlo et al., 2011). Enzymes previously linked to chromosomal translocations in leukemia (Lorsbach et al., 2003), the ten-eleven translocation proteins (TET1, 2 and 3), have been recently implicated as responsible for the oxidation of $5 \mathrm{mC}$ into $5 \mathrm{hmC}$ (Kriaucionis and Heintz, 2009; Tahiliani et al., 2009). Then, the final demethylation process is resolved by enzymes of the DNA repair machinery in the cell (Fig. 4).

The drastic drop in paternal DNA methylation after fertilization (Mayer et al., 2000), attributed earlier to a fast and active demethylation, occurs concurrently with an increase in conversion from $5 \mathrm{mC}$ to $5 \mathrm{hmC}$ (Wossidlo et al., 2011). Conversely, at the maternal genome, an aparent partial "protection" against TET3 prevents the addition of hydroxyl groups in the DNA, leading to a passive demethylation pattern (Nakamura et al., 2012). The mechanism used to control the methylation assumes that $5 \mathrm{hmC}$ interferes with the recognition of methylated cytosines by DNMT1, allowing a passive demethylation pattern to be established (Fig. 4a). Another possible path is explained by the low affinity of the $5 \mathrm{hmC}$ to methyl-CpG binding proteins, which specifically recognize the hydroxymethyl group, e.g., DNA repair proteins as $5 \mathrm{hmC}$-specific DNA glycosylase (5hmC-DG), as shown in Fig. 4b (Dahl et al., 2011).
A. Passive (replication dependent) DNA demethylation

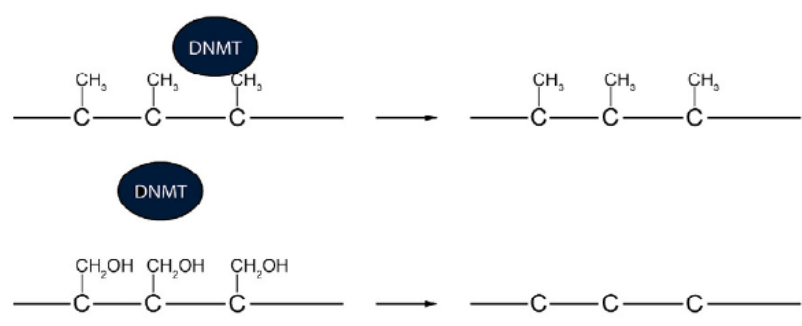

B. Active (replication independent) DNA demethylation

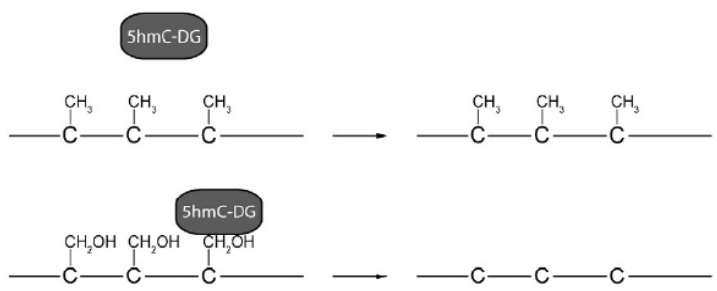

Figure 4. (A) Top: DNA methyltransferase 1 (DNMT) recognizes $5 \mathrm{mC}$ and maintain methylation during DNA replication. Bottom: $5 \mathrm{hmC}$ is not recognized by DNMT, which will prevent maintenance methylation during DNA replication, resulting in passive (replication dependent) DNA demethylation. (B) Top: 5mC is not recognized by DNA repair proteins, maintaining methylation during DNA replication. Bottom: $5 \mathrm{hmC}$ may be recognized by DNA repair proteins, e.g., a $5 \mathrm{hmC}$-specific DNA glycosylase (5hmC-DG), which will convert $5 \mathrm{hmC}$ to cytosine, leading to active (replication independent) DNA demethylation. Adapted from Dahl et al. (2011).

\section{Abnormal patterns of DNA methylation and consequences for development}

Chromatin remodeling after fertilization, associated with the reprogramming of the DNA methylation, appears to occur similarly in embryos produced both in vivo and in vitro (Han et al., 2003). However, several SCNT cloning studies showed that the introduction of the somatic donor nucleus (highly methylated) in a recipient cytoplasm (oocyte) filled with chromatin remodeling components is not sufficient to reprogram, modify or delete certain stable genomic epigenetic markers of differentiation, leading to faulty gene expression patterns (Bird, 2002). This reprogramming failure is associated with the hypermethylation status of DNA in murine and bovine embryos produced by SCNT, which may have similar levels of DNA methylation of the somatic cell donor nucleus (Dean et al., 2001, 2003; Beaujean et al., 2004). This fact can be observed in Fig. 3 above, where a high amount of methylated DNA is maintained after nuclear transfer in mice, while in vivo-derived embryos go through normal processes of replication dependent and independent demethylation.

Due to its role in gene expression, epigenetic modification is considered essential to the memory of a specific cellular function during development (Bird,
2002) and regulation of nuclear reprogramming (Han et al., 2003). The efficiency of epigenetic reprogramming after cloning by SCNT seems to be strongly dependent on the type and state of differentiation of the somatic cell donor used (Wells et al., 2003). In rats and cattle, the type of cell lineage in culture, a cell line or even subclone populations may reveal different developmental capabilities prior to and after cloning (Humpherys et al, 2001; Vichera et al., 2013).

An apparent relationship exists between the process of chromatin remodeling, genome reprogramming, and the profile of DNA methylation. In mice, a significantly higher percentage of blastocysts are obtained when cloned embryos are reconstructed with rather unmethylated cells, such as murine embryonic stem cells (ESC) or primordial germ cells (PGC), than other somatic cell types (Humpherys et al., 2001). In the absence of DNMT1 in the nucleus and after fertilization, the replication generates only unmethylated DNA strands which, over time, leads to passive DNA demethylation, as occurs with zygote DNA from maternal origin. Interestingly, higher amounts of transcripts for DNMT1 were observed in bovine blastocysts derived by cloning SCNT (Wrenzycki et al., 2001), which coincides with the detection of a more methylated state of cloned embryos. Thus, it is possible that the hypermethylated state of 
cloned bovine embryos is associated not only from poor demethylation of nuclear DNA, but also through the presence of active DNMT1 of somatic origin in the nucleus during early development, contributing to hypermethylation.

Genomic imprinting appears to be more susceptible to epigenetic changes, with deregulation of ICRs or DMRs generally resulting in abnormal phenotypes (Rancourt et al., 2013). Consequently, embryonic manipulations, such as IVF and SCNT, seem to deregulate imprinting (Moore, 2001). On the other hand, when DNMT1 activity is reduced, the DNA methylation in ICRs or DMRs associated with genomic imprinting was generally refractory to epigenetic changes, maintaining their methylation patterns in cells in culture (McGraw et al., 2013). However, the permanent loss of DNMT1 by gene deletion leads to a reduction in monoallelic expression of several imprinting genes (McGraw et al., 2013). Interestingly, homozygous DNMT1 mutant mouse embryos null by deletion died between days 9-11 of gestation (JacksonGrusby et al., 2001). The loss of DNMT1, however, had no effect on the proliferative potential of mouse ESC in culture, but the induction of differentiation in these cells also lead to cell death (Rhee et al., 2002). On the other hand, DNMT1 overexpression induces a progressive DNA hypermethylation associated with transcriptional inactivation of several imprinting genes, leading to embryonic lethality (Biniszkiewicz et al., 2002).

It is not surprising that the set of distinct epigenetic features and changes at the transcript levels observed in cloned bovine blastocysts (Wrenzycki et al., 2001) should cause a significant effect in the expression of a variety of imprinting and nonimprinting genes after cloning (Wrenzycki et al., 2001; Bertolini et al., 2002, 2004). Thus, an inadequate activation or inactivation of important developmentally important genes can predispose animals to different degrees of abnormalities after cloning by SCNT, depending on the interaction between qualitative and quantitative discrepancies, subsequent to the level or degree of genome reprogramming obtained after embryo reconstruction (Bertolini et al., 2012). For instance, cells with changes in imprinted genes may be directed to the trophectoderm of cloned embryos, potentially generating defective fetal membranes, as frequently observed after cloning (Wei et al., 2011).

The modified genome configuration of cloned embryos by aberrant DNA methylation patterns may be closely associated with reprogramming failures, altered gene expression profiles, and abnormal embryo development. In cattle, abnormal DNA methylation patterns have been linked to abnormalities after cloning, which in turn can be phenotypically expressed by fetal and placental disorders, increased pre-natal losses and lower postnatal survival (Bertolini and Anderson, 2002; Han et al., 2003; Salilew-Wondim et al., 2013). However, a certain degree of variation in gene expression pattern after cloning, generally attributed to epigenetic features transmitted by the donor cell nucleus, is totally acceptable and compatible with subsequent normal growth, development and survival after birth (Humpherys et al., 2001; Wells et al., 2003).

\section{Manipulation of the epigenetic profile in the somatic cell or the early embryo: there is no silver bullet}

\section{Epigenetic therapy}

Currently, the manipulation of cellular epigenetic profiles, such as DNA methylation levels or histone modifications, has been applied in epigenetic therapy (Daura-Oller et al., 2009). Since the birth of Dolly, the scientific community and the commercial users have been coping with the low efficiency observed after cloning by SCNT, along with the appearance of abnormalities in the course of development, usually referred as the Abnormal Offspring Syndrome (AOS). As abnormal gene expression patterns appear to be a consequence of faulty epigenetic reprogramming after cloning, several potential strategies for improving cloning outcome have been endeavored for use in gametes, somatic cells and/or early developing embryos of several animal especies, as illustrated in Fig. 5 and Tables 1 and 2. Efforts have been dedicated to modulate key cellular events to mold or mimic physiological processes to obtain more suitable cytoplasts and karyoplasts for epigenetic reprogramming, chromatin remodeling, and related biological processes aiming to support proper development pre- and post-natal development after cloning by SCNT. Such attempts to modify epigenetic features of somatic cells or embryos, either at specific targets (DNA methylation, histone modifications, $\mathrm{X}$ chromosome inactivation, Table 1) or for broader alternative epigenetic modifications and/or on processes to enhance embryo activation and development (Table 2) have shown variable results. The basis for the most applied or promising strategies for the epigenetic modulation of mammalian cell nuclei is discussed below.

\section{DNA demethylating strategies}

In oncology, many tumor suppressor genes are silenced by DNA methylation and several chemotherapeutic treatments have been developed to reduce genome methylation in an attempt at reexpressing suppressor genes. Thus, to reduce the DNA methylation levels in cancer cells, demethylating agents, such as the cytidine analogues 5'-aza-cytidine (5-AzaC) or 5'-aza-2'-deoxycytidine (5-Aza-dC), have been used in chemotherapy to inhibit DNA methylation by DNMTs, as the cytidine has a nitrogen at the position 5, instead of a carbon. However, to work, such agents must be incorporated into the genome, which can cause mutations in daughter cells. Some of such strategies using 5-Aza-C and 5-Aza-dC have also been attempted for cloning, with wide-ranging results. Generally, an adverse effect on embryo development is seen after cloning due to exposure of donor cells or embryos to relatively high doses of the cytidine analogues for rather long periods. Therefore, even if used with some success as chemotherapeutic agents in oncology, the demethylating chemicals above are unstable and may 
promote toxic and irreversible long-term effects. These treatments may adversely affect the period of chromatin remodeling of the embryonic genome, which includes the remethylation after the 8-cell stage in cattle (Dean et al., 2003). Other demethylating agents, such as adenosyl homocysteine (SAHA) and zebularine, more stable and less toxic DNMT inhibitors than the previous (Yoo et al., 2004), in addition to other demethylating strategies, including the RNAi-induced depletion of DNMT1 or the overexpression of cytidine deaminase, have been also applied to cells and embryos with promising results.

\section{Increasing histone acetylation}

When acetylation occurs in the histone structure, it becomes less compact, being more permissive to DNA transcription. The use of some chemical agents have been rather successful to increase histone acetylation, mainly by reduce the effects of deacetylase enzymes, aiming at improving cloning efficiency (Table 1). Trichostatin A (TSA) was demonstrated as a potent histone deacetylase inhibitor (HDACi), with greater specificity than other reagents previously used (Yoshida et al., 1990). Since then, TSA has been used to enhance embryo production efficiency by SCNT, as its use increases the amount of acetylated histones and was also related to a decreased histone methylation pattern. Scriptaid is a HDACi structurally similar to TSA, although it is considered more effective and less toxic (Su et al., 2000). Novel HDACi, such as oxamflatin, has been also used in pig embryos, but more studies are needed to verify its efficacy after cloning (Hou et al., 2014).

\section{Histone demethylating strategies.}

Histone 3 methylation of lysines at positions 9 (H3K9) and 27 (H3K27) is associated with transcriptional repression, with $\mathrm{H} 3 \mathrm{~K} 9 \mathrm{me} 3$ being highly correlated with constitutive heterochromatin, which is the condensed, transcriptionally inactive state of chromatin. Recently, histone demethylating modulators, such as BIX-01294 or histone methylases, have been successfully used to increase the overall SCNT cloning efficiency. BIX-01294 inhibits the G9A histone lysine methyltransferase (HMTase), playing a role in $\mathrm{H} 3 \mathrm{~K} 9$ methylation, regulating gene expression and chromatin organization (Kubicek et al., 2007).

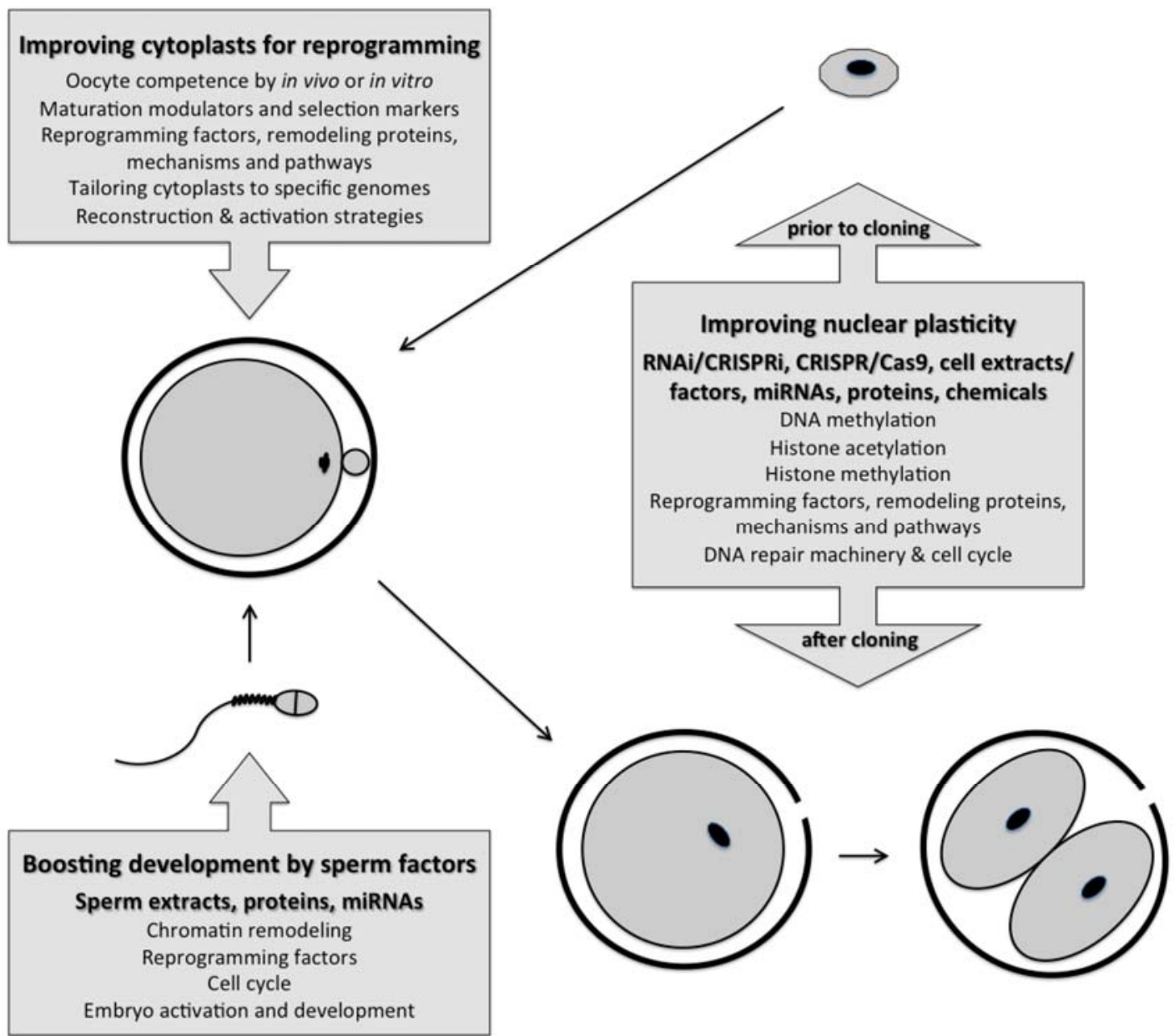

Figure 5. Potential strategies for improving the cloning outcome by the modulation of cellular events in gametes, somatic cells and/or early developing embryos for tailoring more suitable cytoplasts and karyoplasts for epigenetic reprogramming, chromatin remodeling, and related biological processes to support proper development pre- and post-natal development after cloning by SCNT. 
Table 1. Reprogramming strategies to target specific epigenetic modifications in somatic cells or early embryos for cloning by SCNT.

\begin{tabular}{|c|c|c|c|}
\hline $\begin{array}{l}\text { Epigenetic } \\
\text { target }\end{array}$ & Reprogramming strategy & Species and cell type & Outcome \\
\hline \multirow{13}{*}{$\begin{array}{l}\text { DNA } \\
\text { demethylation }\end{array}$} & \multirow{4}{*}{$\begin{array}{l}\text { DNMTi - Cytidine } \\
\text { Analogues }\end{array}$} & Bovine somatic cells & $\begin{array}{l}\text { Treated cells had decreased methylation status, but treatment affected } \\
\text { embryo development to blastocyst stage }\end{array}$ \\
\hline & & $\begin{array}{l}\text { Bovine somatic cells and } \\
\text { one-cell embryos }\end{array}$ & $\begin{array}{l}\text { Use of 5-aza-dC when with TSA provided higher blastocyst rates and } \\
\text { showed significantly lower levels of DNMT1,DNMT3b, HDAC2, and } \\
\text { IGF2 transcripts }\end{array}$ \\
\hline & & $\begin{array}{l}\text { Swine somatic cells and one- } \\
\text { cell embryos }\end{array}$ & $\begin{array}{l}\text { Increased blastocyst rates and OCT4, SOX2, NANOG expression when } \\
\text { used in fetal fibroblast cells }\end{array}$ \\
\hline & & Buffalo somatic cells & $\begin{array}{l}\text { Reduced global methylation and abundance of DNMT1; HDAC1 } \\
\text { decreased when with TSA, also, the blastocyst rates were higher using } \\
\text { cells treated with both reagents }\end{array}$ \\
\hline & DNMTi - Zebularine & $\begin{array}{l}\text { Yak somatic cells and one- } \\
\text { cell embryos }\end{array}$ & $\begin{array}{l}\text { Increased blastocyst rates and histone acetylation of histone } 3 \text { lysine } 9 \\
\text { (H3K9), decreased methylation in promoter regions of OCT4 and SOX2 } \\
\text { genes, when with Scriptaid }\end{array}$ \\
\hline & \multirow{2}{*}{ DNMTi - SAHA } & Bovine one-cell embryos & $\begin{array}{l}\text { Reduced global methylation levels close to what is seen in IVF embryos } \\
\text { when used in SCNT embryos after activation }\end{array}$ \\
\hline & & Bovine one-cell embryos & $\begin{array}{l}\text { Improved development of embryos and reduced DNA global methylation, } \\
\text { when with Scriptaid }\end{array}$ \\
\hline & \multirow[t]{3}{*}{ Cytidine deaminase } & Bovine somatic cells & $\begin{array}{l}\text { Activation-induced cytidine deaminase (AID) overexpressing cells } \\
\text { resulted in higher blastocyst rates and expression of OCT } 4 \text { and NANOG } \\
\text { genes, while its promoter region methylation was reduced }\end{array}$ \\
\hline & & Bovine somatic cells & $\begin{array}{l}\text { Reduced DNA global methylation in treated fibroblasts compared to } \\
\text { control but not reached the IVF embryos level }\end{array}$ \\
\hline & & Bovine somatic cells & $\begin{array}{l}\text { Stable DNMT1 fibroblast lineage was able to develop to blastocyst stage } \\
\text { but failed to carry to term }\end{array}$ \\
\hline & \multirow[t]{3}{*}{ DNMT1 depletion by RNAi } & Bovine somatic cells & $\begin{array}{l}\text { Reduced DNA global methylation, improving in vitro development of } \\
\text { SCNT embryos }\end{array}$ \\
\hline & & Bubaline one-cell embryos & $\begin{array}{l}\text { High development level and lower DNMT expression and protein } \\
\text { abundance }\end{array}$ \\
\hline & & Bovine one-cell embryos & $\begin{array}{l}\text { Reduced DNA global methylation levels without compromising embryo } \\
\text { development }\end{array}$ \\
\hline
\end{tabular}

References

Enright et al., 2003

Wang et al., 2011

Huan et al., 2013

Saini et al. 2014

Xiong et al., 2013

Jafari et al., 2011

Zhang et al., 2014

Ao et al., 2016

Giraldo et al., 2009

Golding et al., 2011

Yamanaka et al., 2011

Selokar et al., 2015

Zhang et al., 2015 


\section{Histone}

acetylation

HDACis - Scriptaid

HDACis - TSA and Sciptaid

HDACis - Oxamflatin

Valproic acid

Histone

demethylation

(H3K9me3)
Bovine somatic cells

Mouse somatic cells

Swine one-cell embryos

Bovine somatic cells and one-cell embryos

Bovine one-cell embryos

Swine one-cell embryos

Swine one-cell embryos

Bubaline embryos

Swine one-cell embryos

Rabbit embryos

Swine embryos

Bovine somatic cells

Mouse somatic cells

Swine one-cell embryos

G9A HMTase inhibitor -

BIX-01294
Histone $\mathrm{H} 3$ acetylation and blastocyst rates were increased causing morphological changes to the cells

Successful mouse cloning of outbred strain using cumulus and fibroblast cells Increased blastocyst rates independently of different cell lines

Improved development to blastocyst; OCT4 and SOX2 expression when with 5-aza-dC; likely, TSA act synergistically with 5-aza-dC

Cloned embryos had increased acetylation but not in pre- and post-

implantation development

Rescued disrupted IGF2/H19 imprinting in piglets; enhanced efficiency producing animals with fewer abnormalities.

Increased overall cloning efficiency and increased acetylation to a pattern similar to IVF embryos

In vitro but not in vivo survival rates were achieved when Scriptaid in

handmade cloned embryos

Increased blastocyst rates of SCNT embryos derived of MII cytoplasts but

not TII, showing that positive effect depends on cell cycle interactions between cytoplast and nuclear donor cells

Increased OCT4 expression and morula and blastocyst rates

Increased blastocyst rates with reduced HDAC activity, also

downregulating DNMT1 expression

Improved blastocyst rate, decreased H3K9me3 levels, enhancing

reprogramming in donor cells

Inducing histone $\mathrm{H} 3 \mathrm{~K} 9 \mathrm{me} 3$ demethylase ectopically expressed, and using cells with H3K9 methyltransferase depletion improved SCNT efficiency

but did not reactivated the reprogramming resistant regions

Enhanced in vitro and in vivo development of embryos, increased OCT4

SOX2, NANOG expression and decreased histone acetylation levels of

$\mathrm{H} 3 \mathrm{~K} 9, \mathrm{H} 4 \mathrm{~K} 8$ and H4K12

Treatment efficiently corrected SCNT-specific aberrant Xist expression at the morula stage and increased survival and overall efficiency to term
Enright et al., 2003

Kishigami et al., 2006

Zhang et al., 2007

Wang et al., 2011

Sangalli et al., 2012

Huan et al., 2015

Zhao et al., 2010

Panda et al., 2012

Rissi et al., 2016

Chen et al., 2013

Hou et al., 2014

Selokar et al., 2013

Matoba et al., 2014

Huang et al., 2016

Matoba et al., 2011

X chromosom

Xist depletion by RNAi

Mouse one-cell embryos

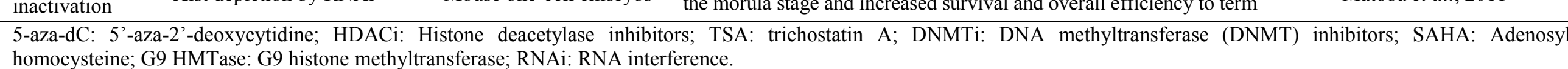

homocysteine; G9 HMTase: G9 histone methyltransferase; RNAi: RNA interference. 


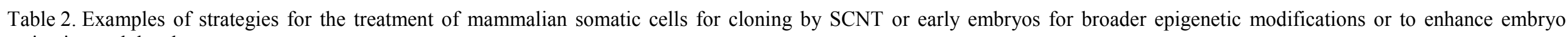
activation and development.

\begin{tabular}{|c|c|c|c|c|}
\hline Target response & Reprogramming strategy & Species and cell type & Outcome & References \\
\hline $\begin{array}{l}\text { Chromatin } \\
\text { remodeling }\end{array}$ & $\begin{array}{l}\text { Protaminization of } \\
\text { somatic cell nuclei }\end{array}$ & $\begin{array}{l}\text { Ovine cells expressing } \\
\text { human protamine }\end{array}$ & $\begin{array}{l}\text { Protaminized nuclei injected into enucleated oocytes efficiently } \\
\text { underwent protamine to maternal histone exchange and developed into } \\
\text { normal blastocysts }\end{array}$ & Iuso et al., 2015 \\
\hline
\end{tabular}

Mouse

Cell fusion

\section{Chromatin}

remodeling,

epigenetic

reprogramming

iPSC cell extract

embryonic/thymic-
lymphocyte hybrid

Biparental and

parthenogenetic neural

stem cells

Swine cell and embryos

Bovine somatic cells

Oocyte extract

Porcine and bovine somatic cells

Ovine somatic cells

Equine/Bovine oocytes

\section{Chromatin}

remodeling,

epigenetic

reprogramming,

embryo activation
Sperm extract $\quad$ Bovine oocytes

Equine oocytes
Demethylation of imprinting and nonimprinting genes and epigenetic modifications compared to reprogramming events during germ cell development

Expression of pluripotency markers in fused cells and methylation of some imprinted genes compared to ESC cells

iPSC extract affected histone modification and gene expression but did not improve blastocyst rates of SCNT embryos

Components of Xenopus leavis oocytes and egg extracts modified the nuclear lamina of bovine fibroblasts inducing a nuclear structural change contributing to reprogramming

Induction of pluripotency markers and reactivation of OCT4 gene in

fibroblasts showing a partial reprogramming to a embryonic state using Xenopus leavis extract

Xenopus leavis extract treatment increased birth rates after SCNT and slightly increased lamb survival to adulthood

Stallion sperm cytosolic extract activated equine and bovine oocytes after injection and developed to cleavage stage

Injection lead to activation of oocyte mechanism, including the completion of the meiotic cell cycle, pronuclear development and antipolyspermy defense

Sperm extract associated with 6-DMAP provided higher cleavage rates of equine SCNT embryos and higher cleavage rates with normal nucleus in equine parthenogenetic embryos
Tada et al., 1997

Jang et al., 2016

No et al., 2015

Alberio et al., 2005

Miyamoto et al., 2007

Rathbone et al., 2010

Choi et al., 2002

Sutovsky et al., 2003

Choi et al., 2004 
Mouse oocytes

Equine oocytes

Embryo activation Sperm proteins

\section{Bovine oocytes}

Mouse oocytes

Equine oocytes
Injection of sperm extract into ICSI oocytes that received non-motile sperm resulted in a significant decrease in blastocyst

development compared with injection of non-motile sperm alone

Injection of sperm extract previous ionomycin treatment obtained higher blastocyst rates and groups of sperm extract injection obtained higher number of live foals, however this result was not statistically significant

Injection of sperm extract for $0,1 \mathrm{sec}$. using Femtojet obtained higher blastocyst rates in equine SCNT

Horse ICSI oocytes injected with lyophilized sperm diluted in sperm extract obtained high blastocysts rates

Mouse PLCz of a single sperm activated mouse oocytes leading to

blastocyst stage; the protein was identified as the trigger of an oocyte to an embryo

Mouse PLCz injection was proven suitable to activate equine oocytes leading to high cleavage rates

Mouse and bovine PLCz injection caused oocyte parthenogenetic activation

Choi et al., 2006

Human PLCz triggered activation of mouse oocytes leading to blastocyst stage when used in a specific range

Mouse PLCz cRNA injection did not increase SCNT blastocyst development when compared to sperm extract
Hinrichs et al., 2007

\section{Choi et al., 2009}

Choi et al., 2011

Saunders et al., 2002

Bedford-Guaus et al., 2008

Ross et al., 2008

Yu et al., 2008

Choi et al., 2009

iPSC: induced pluripotent stem cells; ICSI: intracytoplasmic sperm injection; PLCz: phospholipase C zeta. 


\section{Alternative strategies.}

The use of cell-free systems allows the manipulation of cell programs, by the exchange of nuclear factors between distinct cell types. Fractionated cell homogenates (cell-free extracts) can maintain a biological function and are an important tool for the study of cellular and molecular processes (Alberts et al., 2002), providing a valuable means for examining biological mechanisms associated with nuclear and chromatin remodeling (Kanka, 2003). In fact, the ability of somatic cell extracts to modulate epigenetic reprogramming and chromatin remodeling, activating gene expression in differentiated somatic nuclei have been shown for years. Using this technology, Hakelien et al. (2002) and Landsverk et al. (2002) developed a somatic-cell-free system (stimulated human $\mathrm{T}$ cell extracts) that remodeled chromatin (hyperacetylation of a specific repressed gene promoter) and activated the expression of repressed genes in heterologous differentiated nuclei (293T fibroblasts and resting human $\mathrm{T}$ cell nuclei). Such studies paved the way for further studies on strategies using cell fusion, cell extracts or specific cell factors for the treatment of somatic cells or early embryos for broader-spectrum epigenetic modifications or to enhance embryo activation and development, as illustrated in Table 2. Overall, such systems also have variable results, lacking simplicity and effectivity. However, the identification of factors with biological functions usually become natural candidate molecules to target specific epigenetic modifications in somatic cells or early embryos for cloning by SCNT.

\section{The present and the future: $R N A$-guided epigenetic regulators}

\section{RNA interference (RNAi)}

The process of RNAi is an important posttranscriptional silencing mechanism, conserved in mammalian cells, oocytes and embryos, also significant for the maintenance of genome stability and early development (Svoboda et al., 2004). The RNAi technology has been effectively used for specific mRNA depletion from both mother and zygotic source (Svoboda et al., 2004), providing an efficient approach to induce a transient downregulation of developmentally important molecules, such as DNMTs, either in somatic cells or embryos, without inducing residual effects on the subsequent development (Table 1). Since this technology is potentially less toxic and without prolonged direct residual effect, RNAi can be used as an alternative to the chemical processes used to modulate embryonic reprogramming.

\section{DNA editing and DNA regulation tools}

Programmable nucleases, such as Zinc Finger Nucleases (ZFNs), Transcription Activator-like Effector Nucleases (TALENs) and Clustered Regularly Interspaced Short Palindromic Repeat (CRISPR)/
CRISPR-associated protein (Cas9), have been developed for effective gene editing, and have been broadly used in mammalian organisms (Gaj et al., 2013; Doudna and Charpentier, 2014; Kim and Kim, 2014). The CRISPR/Cas9 system is the most powerful technology and the main gene editor available, due to its versatility and design simplicity (Whitelaw et al., 2016). Yang (2015) has recently demonstrated the power of such tool by performing a one-shot genome-wide inactivation of 62 porcine endogenous retroviruses (PERVs) using a multiplex system. In such way, cells or embryos can be genetically modified either by sitedirected mutations or by gene insertions, generating transgenic founders potentially at a greater efficiency than using traditional methods. In fact, generation of specific double strand breaks (DSBs) by CRISPR/Cas9 has been exploited to modify the genome of livestock species, either through the non-homologous end joining (NHEJ) repair machinery, mostly as gene repressor to disrupt functional alleles (Hai et al., 2014; Ni et al., 2014; Crispo et al., 2015; Wang et al., 2015, Bevacqua et al., 2016), or through the homologous recombination (HR) pathway, for precise gene insertion (Ruan et al., 2015; Jeong et al., 2016; Wu et al., 2016). One example of the usefulness of the CRISPR/Cas9 system in epigenetic reprogramming out of a multitude of possibilities is the knockout of genes coding for histone methyltransferases associated with repressive states of the chromatin or heterochromatin, which will favor gene expression. However, in addition to the gene-editing role, the system CRISPR/Cas9 can also be used as epigenetic repressor or activator without editing the genome, which promises to become the Holy Grail in epigenetic reprogramming of cells, tissues or whole organisms in the near future.

\section{CRISPR interference (CRISPRi)}

Recently, the CRISPR/Cas9 system has gained a new version, the nuclease deactivated Cas9 (dCas9), that blocks transcription in prokaryotic and eukaryotic cells, known as CRISPR interference (CRISPRi), which can be used for the purpose of gene regulation instead of genome editing. As this catalytically dead Cas9 lacks endonuclease activity, it can be used to knock down multiple target genes simultaneously, with reversible effects (Qi et al., 2013). When coexpressed with a guide RNA, CRISPR/dCas9 generates a DNA recognition complex that can specifically interfere with transcriptional elongation, RNA polymerase binding, or transcription factor binding. This new system presents some advantages over the use of RNAi, mainly because the latter causes incomplete silencing of the desired gene (Jackson et al., 2003, Krueger et al., 2007), becoming an excellent alternative to transcriptionally repress genes, moving toward the study of different metabolic pathways in cells and embryos of different mammalian species.

\section{CRISPR activator (CRISPRa)}

In addition to the CRISPRi, the CRISPR/Cas9 
system can be tailored to epigenetically modify the chromatin at specific target sites in the genome, activating silenced genes (CRISPR activating system, or CRISPRa). Such application can benefit the treatment of human epigenetic diseases, such as the Angelman Syndrome, in which a functional parental allele is silenced due to genomic imprinting, whereas the other allele is mutant. In such cases, it is possible to use the CRISPR/Cas9 system as an epigenetic activator of silenced genes, allowing expression of an intact copy of a missing gene (Vora et al., 2016). For instance, Hilton et al. (2015) fused Cas9 to the core catalytic domain of the histone acetyltransferase (HAT) of the human E1Aassociated protein $\mathrm{p} 300$, which allowed the acetylation of the lysine residue at position 27 of Histone 3 (H3K27), activating gene expression. Such tool will soon be also available for other epigenetic applications, as for instance, the use of fused Cas9-demethylases to perform precise and specific DNA demethylation in the genome.

\section{Final considerations and perspectives}

In summary, no silver bullet is available for the precise and complete epigenetic reprogramming of cell nuclei for any given purpose or application. Also, a solid relationship between in vitro treatments and in vivo efficiency is yet to be established (Sangalli et al., 2012; Kim et al., 2015). Moreover, no consensus exists on the usefulness of such epigenetic modulating systems mainly due to differences between species, cell types, doses, combinations, and treatment times between studies, among biological and technical factors, which makes such strategies of limited application.

It is apparent that we are just beginning to understand the epigenetic mechanisms in cell biology, which is the basis for improving genome reprogramming and cloning success. We are also only scratching the surface for the effective and widespread use of novel technologies, especially the RNA-guided epigenetic modulators. Irrespective of the cloning outcome, and due to the low efficiency of the process per se, progress in the field depends and will rely on the development of effective ways to reversibly modulate the epigenetic marks in the donor nucleus by inducing more permissive chromatin states suitable for reprogramming and/or to improve the reprogramming internal milieu in cytoplasts prior and after cloning.

As mankind aquires more knowledge into epigenetics, and as procedures to manipulate gametes, cells and embryos evolve to mimic nature into more homeostatic and homeorhetic physiologic processes, all fields in biology and medicine will advance towards the resolution of problems related to epigenetic programming and inheritance, minimizing random chance, thus improving the odds ratio for successful cloning.

\section{References}

Aguiar LH, Calderón CEM, Gaudencio-Neto S, Rossetto R, Martins LT, Ongaratto FL, Tavares
KCS, Lazzarotto CR, Bertolini LR, Bertolini M. 2016. Quality assessment of goat oocytes and effects on goat cloning efficiency after in vivo or in vitro maturation. Anim Reprod, 13:A297. (abstract).

Alberio R, Brero A, Motliâk J, Cremer T, Wolf E, Zakhartchenko V. 2001. Remodeling of donor nuclei, DNA-synthesis, and ploidy of bovine cumulus cell nuclear transfer embryos: effect of activation protocol. Mol Reprod Dev, 59:371-379.

Alberio R, Johnson AD, Stick R, Campbell KH. 2005. Differential nuclear remodeling of mammalian somatic cells by Xenopus laevis oocyte and egg cytoplasm. Exp Cell Res, 307:131-141.

Alberts B, Johnson A, Lewis J, Raff M, Roberts K, Walter P. 2002. Molecular Biology of the Cell. 4th ed. New York, NY: Garland Science. 1616 pp.

Ao X, Sa R, Wang J, Dao R, Wang H, Yu H. 2016. Activation-induced cytidine deaminase selectively catalyzed active DNA demethylation in pluripotency gene and improved cell reprogramming in bovine SCNT embryo. Cytotechnol, 1-12. doi: 10.1007/s10616-0169988-8

Barnes Fl, Collas P, Powel R, King WA, Westhusin M, Sheperd D. 1993. Influence of recipient oocyte cell cycle stage on DNA synthesis, nuclear envelope breakdown, chromosome constitution, and development in nuclear transplante bovine embryos. Mol Reprod Dev, 36:33-41.

Batchelder CA, Hoffert KA, Bertolini M, Moyer AL, Mason JB, Petkov SG, Famula TR, Anderson GB. 2005. Effect of the nuclear-donor cell lineage, type, and cell donor on development of somatic cell nuclear transfer embryos in cattle. Cloning Stem Cells, 7:238254.

Beaujean N, Taylor J, Gardner J, Wilmut I, Meehan R, Young L. 2004. Effect of limited DNA methylation reprogramming in the normal sheep embryo on somatic cell nuclear transfer. Biol Reprod, 71:185-193.

Bedford-Guaus SJ, Yoon SY, Fissore RA, Choi YH, Hinrichs K. 2008. Microinjection of mouse phospholipase $\mathrm{C}$ zeta complementary RNA into mare oocytes induces long-lasting intracellular calcium oscillations and embryonic development. Reprod Fertil Dev, 20:875-883.

Bertolini M, Anderson GB. 2002. The placenta as a contributor to production of large calves. Theriogenology, 57:181-187.

Bertolini M, Beam SW, Shim H, Bertolini LR, Moyer AL, Famula TR, Anderson GB. 2002. Growth, development and gene expression by in vivo- and in vitro-produced day-7 and day-16 bovine embryos. Mol Reprod Dev, 63:318-328.

Bertolini M, Moyer AL, Mason JB, Batchelder CA, Hoffert KA, Bertolini LR, Carneiro GF, Cargill SL, Famula TR, Calvert CC, Sainz RD, Anderson GB. 2004. Evidence of increased substrate availability to in vitro-derived bovine foetuses and association with accelerated conceptus growth. Reproduction, 128:341354.

Bertolini M, Feltrin C, Gaudencio Neto S, Martins LT, Tavares KCS, Rodrigues VHV, Aguiar LH, Calderón CEM, Almeida JL, Almeida AP, Carneiro 
IS, Costa AKF, Rios DB, Moraes-Junior FJ, Souza MC, Costa RKE, Morais AS, Girão-Neto FXA, Shultz LF, Bertolini M. 2012. Animal cloning: survival of the fittest. Cienc Anim, 22:82-105.

Bevacqua RJ, Fernandez-Martín R, Savy V, Canel NG, Gismondi MI, Kues W, Carlson DF, Fahrenkrug SC, Niemann H, Taboga OA, Ferraris S, Salamone DF. 2016. Efficient edition of the bovine PRNP prion gene in somatic cells and IVF embryos using the CRISPR/Cas9 system. Theriogenology, 28:253-254.

Biniszkiewicz D, Gribnau J, Ramsahoye B, Gaudet F, Eggan K, Humpherys D, Mastrangelo MA, Jun Z, Walter J, Jaenisch R. 2002. Dnmt1 overexpression causes genomic hypermethylation, loss of imprinting, and embryonic lethality. Mol Cell Biol, 22:2124-2135.

Bird A. 2002. DNA methylation patterns and epigenetic memory. Genes Dev, 16:6-21.

Bjornsson HT, Sigurdsson MI, Fallin MD, Irizarry RA, Aspelund T, Cui H, Yu W, Rongione MA, Ekström TJ, Harris TB, Launer LJ, Eiriksdottir G, Leppert MF, Sapienza C, Gudnason V, Feinberg AP 2008. Intra-individual change over time in DNA methylation with familial clustering. $\mathrm{J} \mathrm{Am} \mathrm{Med} \mathrm{Assoc,}$ 299:2877-2883

Bock C, Walter J, Paulsen M, Lengauer T. 2008 Inter-individual variation of DNA methylation and its implications for large-scale epigenome mapping. Nucleic Acids Res, 36:e55.

Bordignon V, Smith LC. 1998. Telophase enucleation: an improved method to prepare recipient cytoplasts for use in bovine nuclear transfer. Mol Reprod Dev, 49:2936.

Briggs R, King TJ. 1952. Transplantation of living nuclei from blastula cells into enucleated frogs' eggs. Proc Natl Acad Sci USA, 38:455-463.

Campbell KHS, Loi P, Otaegui Pj, Wilmut I. 1996. Cell cycle co-ordination in embryo cloning by nuclear transfer. Rev Reprod, 1:40-46.

Campbell KHS, Alberio R, Lee JH, Ritchie WA. 2001. Nuclear transfer in practice. Cloning Stem Cells, 3:201-208

Campbell KHS. 2002. Cell cycle regulation in cloning. In: Cibelli J, Lanza RP, Campbell KHS, West MD (Ed.). Principles of Cloning. San Diego,CA: Academic Press., pp. 391-399.

Campbell KHS, Alberio R, Choi I, Fisher P, Kelly RDW, Lee JH, Maalouf W. 2005. Cloning: eight years after Dolly. Reprod Domest Anim, 40:256-268.

Campbell KHS, Choi I, Zhu J, Fulka J . 2013. Cell cycle regulation in cloning. In: Cibelli J, Wilmut IS, Jaenisch R, Gurdon J, Lanza R, West M, Campbell KH. (Ed.). (2013). Principles of Cloning. San Diego, CA: Academic Press. vol. 2, pp. 149-160.

Chen CH, Du F, Xu J, Chang WF, Liu CC, Su HY, Lin TA, Ju JC, Cheng WTK, Wu SC, Chen YE, Sung LY. 2013. Synergistic effect of trichostatin A and scriptaid on the development of cloned rabbit embryos. Theriogenology, 79:1284-1293.

Chian RC, Nakahara H, Niwa K, Funahashi H. 1992. Fertilization and early cleavage in vitro of ageing bovine oocytes after maturation in culture.
Theriogenology, 37:665-672.

Choi YH, Love CC, Chung YG, Varner DD, Westhusin ME, Burghardt RC, Hinrichs K. 2002. Production of nuclear transfer horse embryos by Piezodriven injection of somatic cell nuclei and activation with stallion sperm cytosolic extract. Biol Reprod, 67:561-567.

Choi YH, Love LB, Westhusin ME, Hinrichs K. 2004. Activation of equine nuclear transfer oocytes: methods and timing of treatment in relation to nuclear remodeling. Biol Reprod, 70:46-53.

Choi YH, Love CC, Varner DD, Hinrichs K. 2006. Equine blastocyst development after intracytoplasmic injection of sperm subjected to two freeze-thaw cycles. Theriogenology, 65:808-819.

Choi YH, Hartman DL, Fissore RA, Bedford-Guaus SJ, Hinrichs K. 2009. Effect of sperm extract injection volume, injection of PLC $\zeta$ cRNA, and tissue cell line on efficiency of equine nuclear transfer. Cloning Stem Cells, 11:301-308.

Choi YH, Varner DD, Love CC, Hartman DL, Hinrichs K. 2011. Production of live foals via intracytoplasmic injection of lyophilized sperm and sperm extract in the horse. Reproduction, 142:529-538.

Crispo M, Mulet AP, Tesson L, Barrera N, Cuadro F, dos Santos-Neto PC, Nguyen TH, Crénéguy A, Brusselle L, Anegón I, Menchaca A. 2015. Efficient generation of myostatin knock-out sheep using CRISPR/Cas9 technology and microinjection into zygotes. PLoS One, 10:e136690.

Dahl C, Grønbak K, Guldberg P. 2011. Advances in DNA methylation: 5-hydroxymethylcytosine revisited. Clin Chim Acta, 412:831-836.

Daura-Oller E, Cabre M, Montero MA, Paternain JL, Romeu A. 2009. Specific gene hypomethylation and cancer: New insights into coding region feature trends. Bioinformation, 3:340-343.

Dean W, Bowden L, Aitchison A, Klose J, Moore T, Meneses JJ, Reik W, Feil R. 1998. Altered imprinted gene methylation and expression in completely ES cell derived mouse fetuses: association with aberrant phenotypes. Development, 125:2273-2282.

Dean W, Santos F, Stojkovic M, Zakhartchenko V, Walter J, Wolf E, Reik W. 2001. Conservation of methylation reprogramming in mammalian development: aberrant reprogramming in cloned embryos. Proc Natl Acad Sci USA, 98:13734-13738.

Dean W, Santos F, Reik W. 2003. Epigenetic reprogramming in early mammalian development and following somatic nuclear transfer. Semin Cell Dev Biol, 14:93-100

Doi A, Park IH, Wen B, Murakami P, Aryee MJ, Irizarry R, Herb B, Ladd-Acosta C, Rho J, Loewer S, Miller J, Schlaeger T, Daley GQ, Feinberg AP. 2009. Differential methylation of tissue- and cancerspecific $\mathrm{CpG}$ island shores distinguishes human induced pluripotent stem cells, embryonic stem cells and fibroblasts. Nature Genet, 41:1350-1353.

Doudna JA, Charpentier E. 2014. Genome editing. The new frontier of genome engineering with CRISPRCas9. Science, 346:1258096.

Enright BP, Kubota C, Yang X, Tian XC. 2003. 
Epigenetic characteristics and development of embryos cloned from donor cells treated by trichostatin A or 5aza-2'-deoxycytidine. Biol Reprod, 69:896-901.

Rhee I, Bachman KE, Park BH, Jair KW, Yen RW, Schuebel KE, Cui HE, Feinberg AP, Lengauer C, Kinzler KW, Baylin SB, Vogelstein B. 2002. DNMT1 and DNMT3b cooperate to silence genes in human cancer cells. Nature, 416:552-556.

Flach G, Johnson Mh, Braude Pr, Taylor As, Bolton VN. 1982. The transition from maternal to embryonic control in the 2-cell mouse embryo. EMBO J, 1:681686.

Fulka J JR, First NL, Moor RM. 1996. Nuclear transplantation in mammals: remodeling of transplanted nuclei under the influence of maturation promoting factor. BioEssays, 18:835-840.

Gaj T, Gersbach CA, Barbas CF. 2013. ZFN, TALEN, and CRISPR/Cas-based methods for genome engineering. Trends Biotechnol, 31:397-405.

Galli C, Lagutina I, Lazzari G. 2003. Introduction to cloning by nuclear transplantation. Cloning Stem Cells, 5:223-232

Gerger RPC, Ribeiro ES, Forell F, Bertolini LR, Rodrigues JL, Ambrosio CE, Miglino MA, Mezzalira A, Bertolini M, Bertolini M. 2010. In vitro development of cloned bovine embryos produced by handmade cloning using somatic cells from distinct levels of cell culture confluence. Genet Mol Res, 9:295302.

Giraldo AM, Lynn JW, Purpera, MN, Vaught TD, Ayares DL, Godke RA, Bondioli KR. 2009. Inhibition of DNA methyltransferase 1 expression in bovine fibroblast cells used for nuclear transfer. Reprod Fertil Dev, 21:785-795.

Golding MC, Westhusin ME. 2003. Analysis of DNA (cytosine 5) methyltransferase mRNA sequence and expression in bovine preimplantation embryos, fetal and adult tissues. Gene Expr Patterns, 3:551-558.

Golding MC, Williamson GL, Stroud TK, Westhusin ME, Long CR. 2011. Examination of DNA methyltransferase expression in cloned embryos reveals an essential role for Dnmt1 in bovine development. Mol Reprod Dev, 78:306-317.

Graf A, Krebs S, Heininen-Brown M, Zakhartchenko V, Blum H, Wolf E. 2014. Genome activation in bovine embryos: review of the literature and new insights from RNA sequencing experiments. Anim Reprod Sci, 149:46-58.

Hai T, Teng F, Guo R, Li W, Zhou Q. 2014. One-step generation of knockout pigs by zygote injection of CRISPR/Cas system. Cell Res, 24:372-375.

Håkelien AM, Landsverk HB, Robl JM, Skålhegg BS, Collas P. 2002. Reprogramming fibroblasts to express T-cell functions using cell extracts. Nature Biotech, 20:460-466.

Han YM, Kang YK, Koo DB, Lee KK. 2003. Nuclear reprogramming of cloned embryos produced in vitro. Theriogenology, 59:33-44.

Heyman Y, Zhou Q, Lebourhis D, Chavatte-Palmer P, Renard JP, Vignon X. 2002. Novel approaches and hurdles to somatic cloning in cattle. Cloning Stem Cells, 4:47-55.
Hilton IB, D'Ippolito AM, Vockley CM, Thakore PI, Crawford GE, Reddy TE, Gersbach CA. 2015. Epigenome editing by a CRISPR-Cas9-based acetyltransferase activates genes from promoters and enhancers. Nat Biotechnol, 33:510-517.

Hinrichs K, Choi YH, Varner DD, Hartman DL. 2007. Production of cloned horse foals using roscovitine-treated donor cells and activation with sperm extract and/or ionomycin. Reproduction, 134:319-325

Hou L, Ma F, Yang J, Riaz H, Wang Y, Wu W, Xiaoliang X, Zhiyuan M, Zhou Y, Lin Z, Wenqin Y, Dequan X, Bo Z, Zhuqing R, Yuanzhu X. 2014. Effects of histone deacetylase inhibitor oxamflatin on in vitro porcine somatic cell nuclear transfer embryos. Cell Reprogram, 16:253-265.

Huan Y, Zhu J, Huang B, Mu Y, Kong Q, Liu Z. 2015. Trichostatin a rescues the disrupted imprinting induced by somatic cell nuclear transfer in pigs. PloS One, 10:e126607.

Huan YJ, Zhu J, Xie BT, Wang JY, Liu SC, Zhou Y, Kong QR, He HB, Liu ZH. 2013. Treating cloned embryos, but not donor cells, with 5-aza-2'deoxycytidine enhances the developmental competence of porcine cloned embryos. J Reprod Dev, 59:442-449.

Huang J, Zhang H, Yao J, Qin G, Wang F, Wang X, Luo A, Zheng Q, Cao C, Zhao J. 2016. BIX-01294 increases pig cloning efficiency by improving epigenetic reprogramming of somatic cell nuclei. Reproduction, 151:39-49.

Humpherys D, Eggan K, Akutsu H, Hochedlinger K, Rideout WM, Biniszkiewwicz D, Yanagimachi R, Jaenish R. 2001. Epigenetic instability in ES cells and cloned mice. Science, 293:95-97.

Huntriss J, Hinkins M, Oliver B, Harris SE, Beazley JC, Rutherford AJ, Gosden RG, Lanzendorf SE, Picton HM. 2004. Expression of mRNAs for DNA methyltransferases and methyl-CpG-binding proteins in the human female germ line, preimplantation embryos, and embryonic stem cells. Mol Reprod Dev, 67:323336.

Irizarry RA, Ladd-Acosta C, Wen B, Wu Z, Montano C, Onyango P, Cui H, Gabo K, Rongione M, Webster M, Ji H, Potash JB, Sabunciyan S, Feinberg AP. 2009. The human colon cancer methylome shows similar hypo- and hypermethylation at conserved tissue-specific $\mathrm{CpG}$ island shores. Nature Genet, 41:178-186.

Iuso D, Czernik M, Toschi P, Fidanza A, Zacchini F, Feil R, Curtet S, Buchou T, Shiota H, Khochbin S, Ptak GE, Loi P. 2015. Exogenous expression of human protamine 1 (hPrm1) remodels fibroblast nuclei into spermatid-like structures. Cell Reports, 13:1765-1761

Jackson AL, Bartz SR, Schelter J, Kobayashi SV, Burchard J, Mao M, Li B, Cavet G, Linsley PS. 2003. Expression profiling reveals off-target gene regulation by RNAi. Nat Biotechnol, 21:635-637.

Jackson-Grusby L, Beard C, Possemato R, Tudor M, Fambrough D, Csankovszki G, Dausman J, Lee P, Wilson C, Lander E, Jaenisch R. 2001. Loss of genomic methylation causes p53-dependent apoptosis and epigenetic deregulation. Nat Genet, 27:31-39. 
Jaenisch R, Bird A. 2003. Epigenetic regulation of gene expression: how the genome integrates intrinsic and environmental signals. Nat Genet, 33:245-254.

Jafari S, Hosseini MS, Hajian M, Forouzanfar M, Jafarpour F, Abedi P, Gourabi H, Shahverdi AH, Dizaj AVT, Anjomshoaa M, Haron W, Noorshariza N, Yakub H, Nasr-Esfahari MH. 2011. Improved in vitro development of cloned bovine embryos using S-adenosylhomocysteine, a non-toxic epigenetic modifying reagent. Mol Reprod Dev, 78:576-584.

Jang HS, Hong YJ, Choi HW, Song H, Byun SJ, Uhm SJ, Seo HG, Do JT. 2016. Changes in parthenogenetic imprinting patterns during reprogramming by cell fusion. PLoS One, 11(5):e0156491.

Jeong YH, Kim YJ, Kim EY, Kim SE, Kim J, Park MJ, Kang MJ. 2016. Knock-in fibroblasts and transgenic blastocysts for expression of human FGF2 in the bovine $\beta$-casein gene locus using CRISPR/Cas9 nuclease-mediated homologous recombination. Zygote, 24:442-456.

Kanka J. 2003. Gene expression and chromatin structure in the pre-implantation embryo. Theriogenology, 59:3-19.

Kato Y, Tani T, Sotomaru Y, Kurokawa K, Kato J, Deguchi H, Yasue H, Tsunoda Y. 1998. Eight calves cloned from somatic cell of a single adult. Science, 282:2095-2098

Kho MR, Baker DJ, Layoon A, Smith SS. 1998. Stalling of human DNA (Cytosine-5) methyltransferase at single strand conformers form a site of dynamic mutation. J Mol Biol, 275:67-79.

Kikyo N, Wolffe AP. 2000. Reprogramming nuclei: insights from cloning, nuclear transfer and heterokaryons. J Cell Sci, 113:11-20.

Kim H, Kim JS. 2014. A guide to genome engineering with programmable nucleases. Nat Rev Genet, 15:321334.

Kim MJ, Oh HJ, Kim GA, Suh HN, Jo YK, Choi YB, Kim HD, Han HJ, Lee BC. 2015. Altering histone acetylation status in donor cells with suberoylanilide hydroxamic acid does not affect dog cloning efficiency. Theriogenology, 84:1256-1261.

Kishigami S, Mizutani E, Ohta H, Hikichi T, Van Thuan N, Wakayama S, Bui HT, Wakayama $T$. 2006. Significant improvement of mouse cloning technique by treatment with trichostatin A after somatic nuclear transfer. Biochem Biophys Res Commun, 340:183-189.

Kriaucionis S, Heintz N. 2009. The nuclear DNA base 5-hydroxymethylcytosine is present in Purkinje neurons and the brain. Science, 324:929-930.

Krueger U, Bergauer T, Kaufmann B, Wolter I, Pilk S, Heider-Fabian M, Kirch S,Artz-Oppitz C, Isselhorst M, Konrad J. 2007. Insights intoeffective RNAi gained from large-scale siRNA validation screening. Oligonucleotides, 17:237-250.

Kubiak JZ, Weber M, Pennart H, Winston NJ, Maro B. 1993.The metaphase II arrest in mouse oocytes is controlled through microtubule-dependent destruction of cyclin B in the presence of CSF. EMBO J, 12:37733778 .
Kubicek S, O'Sullivan RJ, August EM, Hickey ER, Zhang Q, Teodoro ML, Rea S, Mechtler K, Kowalski JA, Homon CA, Kelly TA, Jenuwein T. 2007. Reversal of $\mathrm{H} 3 \mathrm{~K} 9 \mathrm{me} 2$ by a small-molecule inhibitor for the G9a histone methyltransferase. Mol Cell, 25:473481.

Landsverk HB, Håkelien AM, Küntziger T, Robl JM, Skålhegg BS, Collas P. 2002. Reprogrammed gene expression in a somatic cell-free extract. EMBO Rep, 3:384-389.

Li J, Gao Y, Petkov S, Purup S, Hyttel P, Callesen H. 2014. Passage number of porcine embryonic germ cells affects epigenetic status and blastocyst rate following somatic cell nuclear transfer. Anim Reprod Sci, 147:3946

Lister R, Pelizzola M, Dowen RH, Hawkins RD, Hon G, Tonti-Filippini J, Nery JR, Lee L, Ye Z, Ngo QM, Edsall L, Antosiewicz-Bourget J, Stewart R, Ruotti V, Millar AH, Thomson JA, Ren B, Ecker JR. 2009. Human DNA methylomes at base resolution show widespread epigenomic difference. Nature, 462:315322.

Liu T, Dou H, Xiang X, Li L, Li Y, Lin L, Pang X, Zhang Y, Chen Y, Luan J, Xu Y, Yang Z, Yang W, Liu H, Li F, Wang H, Yang H, Bolund L, Vajta G, Du Y. 2015. Factors determining the efficiency of porcine somatic cell nuclear transfer: data analysis with over 200,000 reconstructed embryos. Cell Reprogram, 17:463-471.

Lorsbach RB, Moore J, Mathew S, Raimondi SC, Mukatira ST, Downing JR. 2003. TET1, a member of a novel protein family, is fused to MLL in acute myeloid leukemia containing the $\mathrm{t}(10 ; 11)(\mathrm{q} 22 ; \mathrm{q} 23)$. Leukemia, 17:637-641

Marteil G, Richard-Parpaillon L, Kubiak JZ. 2009. Role of oocyte quality in meiotic maturation and embryonic development. Reprod Biol, 9:203-224

Martins, LT, Gaudêncio-Neto S, Tavares KCS, Calderón CEM, Aguiar LH, Lazzarotto CR, Ongaratto, FL, Rodrigues VHV, Carneiro IS, Rossetto R, Almeida AP, Fernandes CCL, Rondina D, Dias ACO, Chies JM, Polejaeva IA, Rodrigues JL, Forell F, Bertolini LR, Bertolini M. 2016. Developmental outcome and related abnormalities in goats: comparison between somatic cell nuclear transfer- and in vivo -derived concepti during pregnancy through term. Cell Reprogram, 1:1-2.

Matoba S, Inoue K, Kohda T, Sugimoto M, Mizutani E, Ogonuki N, Nakamura $T$, Abe $K$, Nakano $T$, Ishino F, Ogura A. 2011. RNAi-mediated knockdown of Xist can rescue the impaired postimplantation development of cloned mouse embryos. Proc Natl Acad Sci USA, 108:20621-20626.

Matoba S, Liu Y, Lu F, Iwabuchi KA, Shen L, Inoue A, Zhang Y. 2014. Embryonic development following somatic cell nuclear transfer impeded by persisting histone methylation. Cell, 159:884-895.

Mayer W, Niveleau A, Walter J, Fundele R, Haaf $T$. 2000. Embryogenesis: demethylation of the zygotic paternal genome. Nature, 403:501-502.

McGraw S, Oakes CC, Martel J, Cirio MC, de Zeeuw P, Mak W, Plass C, Bartolomei MS, Chaillet R, 
Trasler JM. 2013. Loss of DNMT1o disrupts imprinted $\mathrm{X}$ chromosome inactivation and accentuates placental defects in females. PLoS Genet, 9:e1003873.

Meissner A, Mikkelsen TS, Gu H, Wernig M, Hanna J, Sivachenko A, Zhang $X$, Bernstein BE, Nusbaum C, Jaffe DB, Gnirke A, Jaenisch R, Lander ES. 2008. Genome-scale DNA methylation maps of pluripotent and differentiated cells. Nature, 454:66-770.

Mezzalira JC, Ohlweiler LU, Gerger RPC, Casali R, Vieira FK, Ambrosio CE, Miglino MA, Rodrigues JL, Mezzalira A, Bertolini M. 2011. Production of bovine hand-made cloned embryos by zygote-oocyte cytoplasmic hemi-complementation. Cloning Stem Cells, 13:65-76.

Miyamoto K, Furusawa T, Ohnuki M, Goel S, Tokunaga T, Minami N, Yamada M, Ohsumi K, Imai H. 2007. Reprogramming events of mammalian somatic cells induced by Xenopus laevis egg extracts. Mol Reprod Dev, 74:1268-1277.

Moore T. 2001. Genetic conflict, genomic imprinting and establishment of the epigenotype in relation to growth. Reproduction, 122:185-193.

Nakai M, Ito J, Kashiwazaki N, Men NT, Tanihara F, Noguchi J, Kaneko H, Onishi, A, Kikuchi K. 2016. Treatment with protein kinase $\mathrm{C}$ activator is effective for improvement of male pronucleus formation and further embryonic development of sperm-injected oocytes in pigs. Theriogenology, 85:703-708

Nakamura T, Liu YJ, Nakashima H, Umehara H, Inoue K, Matoba S, Tachibana M, Ogura A, Shinkai Y, Nakano T. 2012. PGC7 binds histone H3K9me2 to protect against conversion of $5 \mathrm{mC}$ to $5 \mathrm{hmC}$ in early embryos. Nature, 486:415-419.

Nan X, Meehan RR, Bird A. 1993. Dissection of the methyl-CpG binding domain from the chromosomal protein MeCP2. Nucleic Acid Res, 21:4886-4892.

Ni W, Qiao J, Hu S, Zhao X, Regouski M, Yang M, Polejaeva IA, Chen C. 2014. Efficient gene knockout in goats using CRISPR/Cas9 system. PLoS One, 9:e106718.

Niemann H. 2016. Epigenetic reprogramming in mammalian species after SCNT-based cloning. Theriogenology, 86:80-90.

No JG, Choi MK, Kwon DJ, Yoo JG, Yang BC, Park JK, Kim DH. 2015. Cell-free extract from porcine induced pluripotent stem cells can affect porcine somatic cell nuclearreprogramming. J Reprod Dev, 61:90-98.

Nurse P. 1990. Universal control mechanism regulating onset of M-phase. Nature, 344:503-507.

Oback B, Wells D. 2002. Donor cells for nuclear cloning: many are called, but few are chosen. Cloning Stem Cells, 4:147-168.

Oback B, Wells DN. 2003. Cloning cattle. Cloning Stem Cells, 5:243-256.

Østrup O, Petrovicova I, Strejcek F, Morovic M, Lucas-Hahn A, Lemme E, Petersen B, Niemann H, Laurincik J, Maddox-Hyttel P. 2009. Nuclear and nucleolar reprogramming during the first cell cycle in bovine nuclear transfer embryos. Cloning Stem Cells, 11:367-375.

Panda SK, George A, Saha A, Sharma R, Singh AK,
Manik RS, Chauhan MS, Palta P, Singla SK. 2012. Effect of scriptaid, a histone deacetylase inhibitor, on the developmental competence of Handmade cloned buffalo (Bubalus bubalis) embryos. Theriogenology, 77:195-200.

Qi LS, Larson MH, Gilbert LA, Doudna JA, Weissman JS, Arkin AP, Lim WA. 2013. Repurposing CRISPR as an RNA-guided platform for sequence-specific control of gene expression. Cell, 152:1173-1183.

Rancourt RC, Harris HR, Barault L, Michels KB. 2013. The prevalence of loss of imprinting of H19 and IGF2 at birth. FASEB J, 27:3335-3343.

Ratajczak MZ. 2012. Igf2-H19, an imprinted tandem yin-yanggene and its emerging role in development, proliferation of pluripotent stem cells, senescence and cancerogenesis. J Stem Cell Res Ther, 2:108.

Rathbone, AJ, Fisher PA, Lee JH, Craigon J, Campbell KHS. 2010. Reprogramming of ovine somatic cells with Xenopus laevis oocyte extract prior to SCNT improves live birth rate. Cell Reprogram, 12:609-616.

Reik W, Murrell A. 2000. Genomic imprinting: silence across the order. Nature, 405:408-409.

Reik W, Dean W, Walter J. 2001. Epigenetic reprogramming in mammalian development. Science, 293:1089-1093.

Ribeiro ES, Gerger RPC, Ohlweiler LU, Ortigari Jr I, Mezzalira JC, Forell F, Bertolini LR, Rodrigues JL, Ambrósio CR, Miglino MA, Mezzalira A, Bertolini M. 2009. Developmental potential of bovine hand-made clone embryos reconstructed by aggregation or fusion with distinct cytoplasmic volumes. Cloning Stem Cells, 11:377-386.

Rissi VB, Glanzner WG, Mujica LK, Antoniazzi AQ, Gonçalves PB, Bordignon V. 2016. Effect of cell cycle interactions and inhibition of histone deacetylases on development of porcine embryos produced by nuclear transfer. Cell Reprogram, 18:8-16.

Ross PJ, Beyhan Z, Iager AE, Yoon SY, Malcuit C, Schellander K, Fissore RA, Cibelli JB. 2008. Parthenogenetic activation of bovine oocytes using bovine and murine phospholipase C zeta. BMC Dev Biol, 8:16.

Ruan J, Li H, Xu K, T, Wu T, Wei J, Zhou J, Liu Z, Mu T, Yang S, Ouyang H, Chen-Tsai RY, Li K. 2015. Highly efficient CRISPR/Cas9-mediated transgene knockin at the H11 locus in pigs. Sci Rep, $5: 14253$.

Saini M, Selokar NL, Agrawal H, Singla SK, Chauhan MS, Manik RS, Palta P. 2014. Treatment of buffalo (Bubalus bubalis) donor cells with trichostatin A and 5-aza-2. Reprod Fertil Dev, 28:824-837.

Salilew-Wondim D, Tesfaye D, Hossain M, Held E, Rings F, Tholen E, Looft C, Cinar U, Schellander K, Hoelker M. 2013. Aberrant placenta gene expression pattern in bovine pregnancies established after transfer of cloned or in vitro produced embryos. Physiol Genomics, 45:28-46.

Sangalli JR, De Bem THC, Perecin F, Chiaratti MR, Oliveira LDJ, de Araujo RR, Pimente JRV, Smith LC, Meirelles FV. 2012. Treatment of nuclear-donor 
cells or cloned zygotes with chromatin-modifying agents increases histone acetylation but does not improve full-term development of cloned cattle. Cell Reprogram, 14:235-247.

Saunders CM, Larman MG, Parrington J, Cox LJ, Royse J, Blayney LM, Swann K, Lai FA. 2002. PLC $\zeta$. a sperm-specific trigger of Ca2+ oscillations in eggs and embryo development. Development, 129:3533-3544.

Selokar NL, John L, Revay T, King WA, Singla SK, Madan P. 2013. Effect of histone deacetylase inhibitor valproic acid treatment on donor cell growth characteristics, cell cycle arrest, apoptosis, and handmade cloned bovine embryo production efficiency. Cell Reprogram, 15:531-542.

Selokar NL, Saini M, Palta P, Chauhan MS, Manik R, Singla SK. 2014. Hope for restoration of dead valuable bulls through cloning using donor somatic cells isolated from cryopreserved semen. PloS One, 9:e90755.

Selokar NL, Saini M, Agrawal H, Palta P, Chauhan MS, Manik R, Singla SK. 2015. Buffalo (Bubalus bubalis) SCNT embryos produced from somatic cells isolated from frozen-thawed semen: effect of trichostatin A on the in vitro and in vivo developmental potential, quality and epigenetic status. Zygote, 24:549-553.

Singh P, Lee DH, Szabó PE. 2012. More than insulator: multiple roles of CTCF at the H19-Igf2 imprinted domain. Front Genet, 3:214.

Sirard MA. 2011. Activation of the embryonic genome. Reprod Domest Rumin, 7:145-158.

Smith SS, Kaplan BE, Sowers LC, Newman EM. 1992. Mechanism of human methyl-directed DNA methyltransferase and the fidelity of cytosine methylation. Proc Natl Acad Sci USA, 89:4748-4744.

Sterthaus O, Skoczylas E, De Geyter C, Bürki K, Ledermann B. 2009. Evaluation of in vitro cultured rat oocytes, from different strains, by spindle morphology and maturation-promoting-factor activity combined with nuclear-transfer experiments. Cloning Stem Cells, 11:463-472.

Su GH, Sohn TA, Ryu B, Kern SE. 2000. A novel histone deacetylase inhibitor identified by highthroughput transcriptional screening of a compound library. Cancer Res, 60:3137-3142.

Sutovsky P, Manandhar G, Wu A, Oko R. 2003 Interactions of sperm perinuclear theca with the oocyte: implications for oocyte activation, anti-polyspermy defense, and assisted reproduction. Microsc Res Tech, 61:362-378.

Svoboda P, Stein P, Anger M, Bernstein E, Hannon GJ, Schultz RM. 2004. RNAi and expression of retrotransposons MuERV-L and IAP in preimplantation mouse embryos. Dev Biol, 269:276-285.

Szollosi D, Czolowska R, Szollosi SM, Tarkowski AK. 1988. Remodeling of mouse thymocyte nuclei depends on the time of their transfer into activated, homologous oocytes. J Cell Sci, 91:603-613.

Szollosi MS, Szollosi D. 1988. "Blebbing" of the nuclear envelope of mouse zygotes, early embryos and hybrid cells. J Cell Sci, 91:257-267.

Tada M, Tada T, Lefebvre L, Barton SC, Surani MA. 1997. Embryonic germ cells induce epigenetic reprogramming of somatic nucleus in hybrid cells. EMBO J, 16:6510-6520.

Tahiliani M, Koh KP, Shen Y, Pastor WA, Bandukwala H, Brudno Y, Agarwal S, Iyer LM, Liu DR, Aravind L, Rao A. 2009. Conversion of 5methylcytosine to 5-hydroxymethylcytosine in mammalian DNA by MLL partner TET1. Science, 324:930-935.

Takahashi, T., Igarashi, H., Amita, M., Hara, S., Matsuo, K., \& Kurachi, H. 2013. Molecular mechanism of poor embryo development in postovulatory aged oocytes: mini review. J Obstet Gynaecol Res, 39):1431-1439.

Tecirlioglu RT, Cooney MA, Lewis IM, Korfiatis NA, Hodgson R, Ruddock NT, Vajta G, Downie S, Trounson AO, Holland MK, French AJ. 2005. Comparison of two approaches to nuclear transfer in the bovine: hand-made cloning with modifications and the conventional nuclear transfer technique. Reprod Fertil Dev, 17:573-585.

Tucker KL. 2001. Methylated cytosine and the brain: a new base for neuroscience. Neuron, 30:649-652.

Turunen MP, Ylä-Herttuala S. 2011. Epigenetic regulation of key vascular genes and growth factors. Cardiovasc Res, 90:441-446.

Urrego R, Herrera-Puerta E, Chavarria NA, Camargo O, Wrenzycki $\mathbf{C}$, Rodriguez-Osorio $\mathbf{N}$. 2015. Follicular progesterone concentrations and messenger RNA expression of MATER and OCT-4 in immature bovine oocytes as predictors of developmental competence. Theriogenology, 83:1179-1187.

Vajta G, Lewis IM, Trounson AO, Purup S, Maddox-Hyttel P, Schmidt M, Pedersen HG, Greve T, Callesen H. 2003. Handmade somatic cell cloning in cattle: analysis of factors contributing to high efficiency in vitro. Biol Reprod, 68:571-578.

Vichera G, Olivera R, Salamone D. 2013. Oocyte genome cloning used in biparental bovine embryo reconstruction. Zygote, 21:21-29.

Vora S, Tuttle M, Cheng J, Church G. 2016. Next stop for the CRISPR revolution: RNA guided epigenetic regulators. FEBS J, 283:3181-3193.

Wakayama S, Cibelli JB, Wakayama T. 2003. Effect of timing of the removal of oocyte chromosomes before of after injection of somatic nucleus on development of NT embryos. Cloning Stem Cells, 5:181-189.

Wakayama T, Perry ACF, Zuccotti M, Johnson KR, Yanagimachi R. 1998. Full-term development of mice from enucleated oocytes injected with cumulus cell nuclei. Nature, 364:369-374.

Wang X, Zhou J, Cao C, Huang J, Hai T, Wang Y, Zheng Q, Zhang H, Qin G, Miao X, Wang H, Cao S, Zhou Q, Zhao J. 2015. Efficient CRISPR/Cas9mediated biallelic gene disruption and site-specific knockin after rapid selection of highly active sgRNAs in pigs. Sci Rep, 5:13348.

Wang Y, Su J, Wang L, Xu W, Quan F, Liu J, Zhang Y. 2011. The effects of 5-aza-2-deoxycytidine and trichostatin a on gene expression and dna methylation status in cloned bovine blastocysts. Cell Reprogram, 3:297-306

Wei Y, Huan Y, Shi Y, Liu Z, Bou G, Luo Y, Zhang 
L, Yang C, Kong Q, Tian J, Xia P, Sun QY, Liu ZH. 2011. Unfaithful maintenance of methylation imprints due to loss of maternal nuclear Dnmt1 during somatic cell nuclear transfer. PLoS One, 6:e20154.

Wells DN, Oback B, Laible G. 2003. Cloning livestock: a return to embryonic cells. Trends Biotechnol, 21:428-432.

Wells DN. 2010. Nuclear transfer: the importance of donor and recipient cells for nuclear reprogramming and cloning efficiency in mammals. Acta Sci Vet, 38:487-507. Wen D, Banaszynski LA, Liu Y, Geng F, Noh KM, Xiang J, Elemento O, Rosenwaks Z, Rafii S. 2014 Histone variant H3. 3 is an essential maternal factor for oocyte reprogramming. Proc Natl Acad Sci USA, 111:7325-7330

Whitelaw CB, Sheets TP, Lillico SG, Telugu BP. 2016. Engineering large animal models of human disease. J Pathol, 238:247-256.

Wilmut I, Schnieke AE, Mcwhir J, Kind AJ, Campbell KHS. 1997. Viable offspring derived from fetal and adult mammalian cells. Nature, 385:810-813.

Wossidlo M, Nakamura T, Lepikhov K, Marques CJ, Zakhartchenko V, Boiani M, Arand J, Nakano T, Reik W, Walter J. 2011. 5-Hydroxymethylcytosine in the mammalian zygote is linked with epigenetic reprogramming. Nature Commun, 2:241.

Wrenzycki C, Wells D, Herrmann D, Miller A, Oliver J, Tervit R, Niemann H. 2001. Nuclear transfer protocol affects messenger RNA expression patterns in cloned bovine blastocysts. Biol Reprod, 65:309-317.

Wu M, Wei C, Lian Z, Liu R, Zhu C, Wang H, Cao J, Shen Y, Zhao F, Zhang L, Mu Z, Wang Y, Wang X, Du L, Wang C. 2016. Rosa26-targeted sheep gene knock-in via CRISPR-Cas9 system. Sci Rep, 6:24360.

Xiong X, Lan D, Li J, Zhong J, Zi X, Ma L, Wang Y. 2013. Zebularine and scriptaid significantly improve epigenetic reprogramming of yak fibroblasts and cloning efficiency. Cell Reprogram, 15:293-300.

Yamanaka KI, Sakatani M, Kubota K, Balboula AZ, Sawai K, Takahashi M. 2011. Effects of downregulating DNA methyltransferase 1 transcript by RNA interference on DNA methylation status of the satellite I region and in vitro development of bovine somatic cell nuclear transfer embryos. J Reprod Dev, 57:393-402.

Yang X, Smith SL, Tian XC, Lewin HA, Renard JP, Wakayama T. 2007. Nuclear reprogramming of cloned embryos and its implications for therapeutic cloning. Nature Genet, 39:295-302.

Yang L, Güell M, Niu D, George H, Lesha E, Grishin D, Aach J, Shrock E, Xu W, Poci J, Cortazio R, Wilkinson RA, Fishman JA, Church J. 2015. Genome-wide inactication of porcine endogenous reptroviruses (PERVs). Science, 350:1101-1104.

Yoo CB, Cheng JC, Jones PA. 2004. Zebularine: a new drug for epigenetic therapy. Biochem Soc Trans, 32:910-912.

Yoshida M, Kijima M, Akita M, Beppu T. 1990. Potent and specific inhibition of mammalian histone deacetylase both in vivo and in vitro by trichostatin A. $J$ Biol Chem, 265:17174-17179.

Yu Y., Saunders CM, Lai FA, Swann K. 2008. Preimplantation development of mouse oocytes activated by different levels of human phospholipase $\mathrm{C}$ zeta. Hum Reprod, 23:365-373.

Zhang H, Wang Y, Sang Y, Zhang Y, Hua S. 2014. Combination of S-adenosylhomocysteine and scriptaid, a non-toxic epigenetic modifying reagent, modulates the reprogramming of bovine somatic-cell nuclear transfer embryos. Mol Reprod Dev, 81:87-97.

Zhang H, Wang L, Li W, Mao Q, Wang Y, Li Q, Hua S, Zhang Y. 2015. A simple and efficient method to transfect small interference RNA into bovine SCNT embryos. Theriogenology, 84:846-852.

Zhang Y, Li J, Villemoes K, Pedersen AM, Purup S, Vajta G. 2007. An epigenetic modifier results in improved in vitro blastocyst production after somatic cell nuclear transfer. Cloning Stem Cells, 9:357-363.

Zhao J, Hao Y, Ross JW, Spate LD, Walters EM, Samuel MS, Rieke A, Murphy CN, Prather RS. 2010. Histone deacetylase inhibitors improve in vitro and in vivo developmental competence of somatic cell nuclear transfer porcine embryos. Cell Reprogram, $12: 75-83$ 